\title{
Current progress in the development of a prophylactic vaccine for HIV-I
}

This article was published in the following Dove Press journal:

Drug Design, Development and Therapy

21 December 2010

Number of times this article has been viewed

\author{
Lena J Gamble' \\ Qiana L Matthews ${ }^{1,2}$ \\ 'Division of Human Gene Therapy, \\ Departments of Medicine, Pathology, \\ Surgery, Obstetrics and Gynecology, \\ The Gene Therapy Center, ${ }^{2}$ Center \\ for AIDS Research, University of \\ Alabama at Birmingham, Birmingham, \\ AL, USA
}

\begin{abstract}
Since its discovery and characterization in the early 1980s as a virus that attacks the immune system, there has been some success for the treatment of human immunodeficiency virus-1 (HIV-1) infection. However, due to the overwhelming public health impact of this virus, a vaccine is needed urgently. Despite the tireless efforts of scientist and clinicians, there is still no safe and effective vaccine that provides sterilizing immunity. A vaccine that provides sterilizing immunity against HIV infection remains elusive in part due to the following reasons: 1) degree of diversity of the virus, 2) ability of the virus to evade the hosts' immunity, and 3) lack of appropriate animal models in which to test vaccine candidates. There have been several attempts to stimulate the immune system to provide protection against HIV-infection. Here, we will discuss attempts that have been made to induce sterilizing immunity, including traditional vaccination attempts, induction of broadly neutralizing antibody production, DNA vaccines, and use of viral vectors. Some of these attempts show promise pending continued research efforts.
\end{abstract}

Keywords: HIV, prophylactic vaccine, AIDS, viral vectors, sterilizing immunity

\section{Introduction}

Since its discovery and characterization in the early 1980 s as a virus that attacks the immune system, leaving patients unable to fight off opportunistic infections, there has been an ebb and flow of effective treatments and hope as scientists continue to search for ways to eradicate human immunodeficiency virus-1 (HIV-1) from the human population similar to what has been accomplished in the case of smallpox. The majority of the effort and nearly all of the success has come in the area of patient treatment rather than inhibition of contraction or spread of the virus. A class of treatments, antiretroviral therapies (ARTs) and later highly active antiretroviral therapies (HAARTs), has been the mainstay of disease control during the last 15 years. Notwithstanding the increased life span of patients, increased time to full-blown AIDS, and decreased contraction of opportunistic infections and AIDS-related diseases (ie, non-Hodgkin's lymphoma, Kaposi's sarcoma, etc) by patients treated with HAART, there are several reasons why development of an HIV-1 vaccine is still warranted. Five of these reasons are as follows: 1) nearly two-thirds of the patients who contract HIV-1 live in underdeveloped countries and cannot afford the expensive HAART regimen, ${ }^{1} 2$ ) both the ART and HAART regimen are complex and are disruptive to patients' lives and diets, making long-term compliance an issue ${ }^{2} 3$ ) the potential side effects of ART/HAART treatments negatively affect the long-term health of patients and include diabetes, cardiovascular disease, fractures, etc, ${ }^{3-5} 4$ ) development of HAART drug resistance,
Correspondence: Qiana L Matthews Division of Human Gene Therapy, Department of Medicine, University of Alabama at Birmingham, 90I 19th Street South, BMR2-R534, Birmingham,

AL 35294, USA

Tel + I 2059340573

Fax +I 2059757476

Email qlm@uab.edu 
and 5) the presence of latent HIV-1 reservoirs harboring viral strains that were produced through mutation throughout the duration of the infection of the host also play a role in the failure of HAART. ${ }^{6}$ These reasons, as well as many others, underscore the need for a prophylactic HIV-1 vaccine.

Possibly, the strongest argument for development of a prophylactic vaccine may be the need for control of the virus spread worldwide. Every day, 7500 patients worldwide are infected with HIV-1. ${ }^{1}$ Production of a vaccine that could inhibit infection, reduce spread, or both would aid in the reduction of the burden of AIDS and AIDS-related diseases. The expenses incurred by the AIDS epidemic can hardly be calculated. They range from tens of thousands of dollars per patient for the HAART regimen, to millions of dollars required for building of orphanages by governments for children whose parents have succumbed to the disease, to the unknown cost of educational materials and condoms in the effort to prevent further spread of the disease. This public health challenge has not gone unnoticed and has been addressed by scientists' ongoing efforts to develop a safe and effective HIV-1 vaccine.

\section{Prophylactic vs therapeutic vaccines}

A prophylactic HIV-1 vaccine would offer sterilizing immunity to patients, preventing infection upon presentation of the virus. A prophylactic vaccine must also be effective at all possible portals of HIV-1 entry, especially the mucosa. ${ }^{7}$ For this to occur, the vaccine must offer broad and durable immunity. Several consortia have worked diligently to produce a vaccine that will induce broadly reactive neutralizing antibodies (Nabs). These consortia include major international efforts as well as efforts of individual countries, regions, and institutions including, but not limited to: the International AIDS Vaccine Initiative Neutralizing Antibody Consortium, ${ }^{8}$ the Center for HIV-AIDS Vaccine Immunology, the HIV Vaccine Trials Network, US Military HIV Research Program, the Collaboration for AIDS Vaccine Discovery, and the Vaccine Research Center at the National Institutes of Allergy and Infectious Diseases of the National Institutes of Health. To date, however, no HIV-1 candidate vaccine has induced broadly reactive Nabs. ${ }^{8}$

In the absence of a vaccine that can prevent infection of HIV-1, there are still many benefits to be realized from production of a therapeutic vaccine. A therapeutic vaccine would be supremely valuable if it were able to increase the titer of virus necessary for infection, increase the time to clinical manifestation of virus, control viral load after infection, and reduce secondary transmission..$^{9-13}$ A vaccine that could induce this type of response would invariably decrease contagiousness, decrease the need for costly and potentially dangerous ART/HAART, and decrease the number of opportunistic infections of patients.

While the effect of controlling the normal HIV-1 pathology with therapeutic vaccines will be favorable for the individual patient as well as society, the effect of preventing HIV-1 infections in humans with a prophylactic vaccine is also broadly appealing. This potential for eradicating the HIV-1 virus from human hosts drives scientists to continue to find ways to circumvent the challenges presented by this unique virus in order to induce production of the Nabs that are critical for sterilizing immunity. This review, therefore, will focus on the specific challenges presented by HIV-1 and strides that have been made toward creating a prophylactic vaccine, including past efforts that have failed and lessons that have been learned from those failures. We will also discuss novel vaccine options and some of the promising trials that are currently underway.

\section{Current challenges to creating an HIV-I vaccine}

While several problems face scientists who are attempting to create an HIV-1 vaccine, three problems in particular have posed extremely daunting challenges. These three problems are 1) degree of diversity of the virus, 2) ability of the virus to evade the hosts' immunity, and 3) lack of appropriate animal models in which to test vaccine candidates. These three major problems will be discussed in more detail below.

\section{Degree of diversity}

Traditionally, prophylactic vaccines have been made by exposing some part of a pathogen's structure as an antigen to the host's immune system, and eliciting an immune response, resulting in the production of long-term memory lymphocytes that are capable of mounting a strong immune response upon later infection with the pathogen. The premise upon which this manipulation of the immune system is based is the ability of the immune system to make long-lasting antibodies to conserved structures on exposed proteins that are native to the pathogen. Ideally, both humoral and cell-mediated immunity would be induced creating long-lasting immunity. Traditional attempts to recreate this process using live attenuated simian immunodeficiency virus-1 (SIV-1) viruses in an effort to vaccinate macaques against SIV-1 have been proven safe and effective in macaques that were subsequently challenged with SIV-1. ${ }^{14,15}$ However, an incidental study of the effect of liveattenuated HIV-1 (containing deletions of the nef gene and 
the long terminal repeat) was proven pathogenic in humans when three out of six treated patients developed late-onset immunosuppression. ${ }^{16-18}$ Killed viruses have also been tested as a potential vaccine approach, but safety concerns have halted their use. These safety concerns include incomplete inactivation of the virus leading to potential residual infectivity during the vaccine preparation. ${ }^{19}$ Due to the ineffectiveness of traditional vaccine approaches to date, scientists have attempted to use recombinant HIV-1 proteins to stimulate the production of Nabs. These attempts failed due to their inability to induce a lasting, broad range of Nabs that would inhibit infection in humans. ${ }^{20-23}$ Perhaps these failures are a result of the inherent diversity of HIV-1. This diversity has presented a major roadblock to development of a prophylactic vaccine. There are three main groups of HIV-1 (M, O, and N $)^{24}$ as well as a recently discovered group, $\mathrm{P}^{25}$ Each group consists of several subtypes, clades. The various clades display biological differences with respect to transmission, ${ }^{26}$ replication, ${ }^{27}$ and disease progression. ${ }^{28,29}$ These differences result in an inability to produce a generalizable vaccine that would induce the breadth of Nabs necessary to counter an infection by a wide range of HIV-1 clades that may be encountered in a natural setting. ${ }^{30}$ The degree of diversity seen in HIV-1 is greater than that of any other virus observed. ${ }^{31,32}$ This problem is being addressed by development of multiclade (multiple env and/ or subtype B gag, pol, nef) $)^{33,34}$ and mosaic vaccines which incorporate sets of 10 immunogenic proteins from 4 different clades or bivalent proteins from clades B and C. ${ }^{35-37}$ There are proof of principle studies that illustrate immunological protection against HIV-1 in nonhuman primates that were passively treated with broadly reactive Nabs. ${ }^{38-40}$ These studies show that protection against infection with HIV-1 can be conferred by the presence of broadly reactive Nabs. The next step toward production of a prophylactic vaccine would involve induction of production of these or similar broadly reactive Nabs by the host's immune system.

\section{Immune evasion}

The rate at which the HIV-1 virus mutates, due to the nature of the reverse transcriptase enzyme responsible for transcribing its RNA, ensures that nearly every daughter virion will have a different genome than its parent. ${ }^{41}$ When these changes occur in the HIV-1 Env protein that is needed for antibody recognition, they inhibit the immune system's ability to mount a sufficient response. One attempt to circumvent this problem has been to induce the production of Nabs to the conserved regions of HIV-1 proteins. A major problem with this approach is that the conserved regions of HIV-1 proteins are often shielded from exposure to Nabs within the HIV-1 envelope. The native structure of the envelope protein, reportedly the only HIV-1 protein susceptible to Nabs, ${ }^{31}$ shields it from the immune system as a glycosylated trimer of heterodimers. The glycosylation of the envelope protein allows for the carbohydrates to masquerade as 'self' thereby forming an immunologically silent face and protects neighboring epitopes via an 'evolving glycan shield'. ${ }^{42-44}$ Additionally, the gp41 coreceptor binding site, another conserved site, is not presented until primary binding to $\mathrm{CD}^{+}{ }^{+}$has occurred..$^{45}$ An attempt to create antibodies to the CD4-binding region of the gp 120 protein was made in rhesus macaques in 2007 and results indicated that vaccinated hosts were able to withstand challenge with SHIV. ${ }^{46}$ Other attempts to create an HIV-1 vaccine have focused on overcoming the ability of HIV-1 to escape immune surveillance through use of antibodies that are able to neutralize diverse isolates of HIV-1. These antibodies include PG9, PG16, ${ }^{47}$ 2F5, 2G12, 4E10, b12, ${ }^{48-51}$ and most recently $\mathrm{sCD} 4-17 \mathrm{~b}^{52}$ and others. ${ }^{53}$ Identification of these antibodies gives hope that their induction or the induction of other such broadly reactive Nabs may provide the basis for a prophylactic vaccine in the future.

\section{Lack of appropriate animal models}

The use of animal models for development of therapeutics offers the benefit of thorough testing and validation prior to introduction of a vaccine in humans. In the past, vaccines were made by observing and then mimicking the immune response mounted by individuals who had recovered from a particular disease. To date, however, there are no known cases of individuals who have recovered from HIV-1 infection. However, data can be gathered from long-term nonprogressors - patients who have been infected with HIV-1 for at least 7 years and do not display any HIV-1-related symptoms. ${ }^{54,55}$ Another option that may be critical to the development of a prophylactic vaccine is the use of relevant animal models. Such models will allow for analysis of the effect of a potential vaccine on an intact host prior to use in humans.

One particular challenge with the use of animal models for development of a prophylactic HIV-1 vaccine is that there are very few naturally occurring disease models of HIV-1. Only a few nonhuman primates are susceptible to infection with HIV-1 and infected animals do not progress to AIDS. ${ }^{56}$ Therefore, it is important to use other disease models that mimic the HIV-AIDS pathologic progression. ${ }^{57}$ One such potential model is feline immunodeficiency virus (FIV). FIV was discovered in 1986 and is known to cause an AIDS-like disease in domestic cats and mimics HIV-related dementia 
in humans. ${ }^{58} \mathrm{~A}$ vaccine for FIV was approved by the FDA in $2002 .{ }^{59}$ While the FIV model is potentially informative, its use is not sufficient as a basis for development of a prophylactic HIV-1 vaccine.

An ideal animal model would display a pathological response to infection with HIV-1 that is very similar to the one that occurs in humans. Unfortunately, HIV-1 does not cause pathology leading to the development of AIDS in any host other than humans. ${ }^{60-63}$ However, animal models have been developed and used that allow partial understanding of the pathology of HIV-1, the natural immunological response to infection, and the response of the host to novel therapeutics. One of these models involves the simian immunodeficiency virus $_{\text {MAC }}\left(\mathrm{SIV}_{\mathrm{MAC}}\right)$ that replicates and causes an AIDS-like disease in baboons, cynomolgus, and pigtailed macaques. While the similarities of $\mathrm{SIV}_{\mathrm{MAC}}$ to HIV-1 have allowed for insight into pathology, transmission, and immunological response of the infected host to the virus, the differences between SIV $_{\text {MAC }}$ and HIV-1 are still too great to be able to draw conclusions regarding potential human responses to an HIV-1 prophylactic vaccine. ${ }^{63}$ Therefore, to broaden the scope of animal model usage, a chimeric SHIV virus was engineered to incorporate both SIV and HIV-1 proteins or genes. ${ }^{64}$ While macaques infected with SHIV do go on to develop AIDS, the time to progression is much different from the time to progression to AIDS of HIV-1-infected humans. Infection of macaques with SIV mac $_{251}$ strain mimics HIV-1 infection in humans by leading to chronic, slow disease progression. Route and dose required for infection, viral tropism, replicative capacity of the viruses, and pathology of SIV/SHIV-infected monkeys are all very different than these parameters in humans. ${ }^{65,66}$ This distinction has been well characterized by the recent Phase IIb STEP trial, which involved 3000 healthy, uninfected volunteers. The result of this trial was termination at its first scheduled efficacy assessment due to its failure to suppress viral load in subsequently infected individuals and then-suspected increased HIV-1 infection due to interaction of the immune system with vaccine components. ${ }^{67}$ The vaccine, a recombinant adenovirus serotype 5 (Ad5) virus incorporating the gag, pol, and nef genes from HIV-1, had been previously tested in an SHIV model in macaques and the results of that experiment were not suggestive of the results of the human trial. ${ }^{68}$

This disparity underscores the need for animal models that more closely reflect the pathology seen in human infection with HIV-1 as well as identification of immunological correlates of protection that reflect control of HIV-1 viral load in human subjects. Therefore, the search for an appropriate animal model or the appropriate use of current animal models in the search for a prophylactic HIV-1 vaccine continues. Until a model can be derived that will allow for observation of each stage of infection, progression of disease, and response of the immune system in a way that is comparable to this process in humans, we will not be able to logically predict which vaccine candidates should be moved forward to clinical trials.

Several attempts to stimulate the immune system to provide protection against HIV infection have been attempted so far (Table 1). Hope for creating a prophylactic vaccine lies in the ability of the scientific community to identify and induce a broad neutralizing antibody response that would offer sterilizing immunity to vaccinated patients. To this end, several novel approaches are being studied.

\section{Novel vaccine options}

As mentioned in the previous section, there are several daunting problems facing scientists who are attempting to create an HIV-1 vaccine. In hopes of creating a vaccine which elicits sterilizing immunity to HIV-1, researchers have focused their efforts on (1) the use of plasmid DNA vaccines, (2) live recombinant vectors for vaccine development (expressing or presenting HIV antigens), and (3) mucosal immunity. These critical topics will be discussed in more detail below.

\section{Plasmid DNA vaccines}

Vaccines should elicit a robust immune response that is long lasting and is able to provide protection against various strains of a pathogen. Plasmid DNA vaccinations can induce a strong humoral and T-cell response. DNA-based vaccination has been used as a powerful tool to fight against parasitic, fungal, bacterial, and viral infections. ${ }^{115-119}$ There are multiple advantages for using plasmid DNA for vaccination: they are generally safe, nontoxic, and through the delivery of a gene encoding important immunogenic epitopes, the DNAbased vaccine exploits biosynthetic machinery of the host cell. One such example was in 1990, whereby Wolff and colleagues illustrated protein expression after intramuscular (IM) injection of plasmid DNA into myocytes. ${ }^{120}$ Despite these promising results, there had been speculation regarding DNA vaccination strategies. For example, it was shown that protein production in response to DNA plasmids that contained HIV inserts elicited substantial cellular response in mice and nonhuman primates. However, these products were poorly immunogenic in humans.

One strategy to improve immune response of the plasmid DNA vaccine strategy is by coadministration of DNA 
Table I Historical vaccine attempts to inhibit HIV-I infection

\begin{tabular}{|c|c|c|c|}
\hline Vaccine attempt & Mechanism of action & Outcome & References \\
\hline \multicolumn{4}{|l|}{ Live attenuated } \\
\hline Nef-deleted viruses & $\begin{array}{l}\text { Deletion of nef gene in SIV; } \\
\text { deletion of nef gene in HIV }\end{array}$ & $\begin{array}{l}\text { Excellent short-term protection in } \\
\text { nonhuman primates. Disease-causing } \\
\text { mutants generated from vaccine }\end{array}$ & $14,69-72$ \\
\hline SIVIAII & Deletion of $v p r$ and a portion of gp4l & $\begin{array}{l}\text { Animals never developed immunodeficiency } \\
\text { but were not protected against challenge } \\
\text { with wild-type virus }\end{array}$ & 73 \\
\hline $\mathrm{SIV}_{\mathrm{MAC}}-\mathrm{M} 4$ & $\begin{array}{l}\text { Multiple mutations in the transmembrane protein } \\
\text { intracytoplasmic domain }\end{array}$ & $\begin{array}{l}\text { Animals developed immunodeficiency I year } \\
\text { after infection with this virus but showed low } \\
\text { or undetectable viremia levels I year } \\
\text { post-challenge with } \text { SIV }_{25 \text { I }}\end{array}$ & 74 \\
\hline \multicolumn{4}{|l|}{ Whole inactivated HIV-Ia } \\
\hline Simian model & $\begin{array}{l}\text { Formaldehyde-inactivated or subunit SIV } \\
\text { vaccines }\end{array}$ & $\begin{array}{l}\text { Animals resistant to infection with HIV } \\
\text { produced in human cells but not HIV } \\
\text { produced in macaque cells }\end{array}$ & $75-77$ \\
\hline Feline model & Dual inactivated strains used for vaccination & $\begin{array}{l}\text { Protection against heterologous } \\
\text { strains conferred }\end{array}$ & $78-81$ \\
\hline \multicolumn{4}{|c|}{ Protein subunits and synthetic peptides } \\
\hline $\begin{array}{l}\text { Recombinant env } \\
\text { glycoproteins }\end{array}$ & Stimulate humoral immune response & $\begin{array}{l}\text { Some antibody production and lymphocyte } \\
\text { proliferation but no clinical benefit to date }\end{array}$ & $82-90$ \\
\hline Recombinant Gag subunits & Stimulate humoral response & $\begin{array}{l}\text { Induced production of anti-p24 antibodies } \\
\text { but no clinical benefit }\end{array}$ & $91-94$ \\
\hline \multicolumn{4}{|l|}{ DNA vaccines } \\
\hline Direct injection & Encoding HIV-I env and rev & $\begin{array}{l}\text { Produced a robust humoral and } \\
\text { cellular response }\end{array}$ & 95 \\
\hline \multicolumn{4}{|c|}{ Viral vectors expressing HIV-I genes } \\
\hline Retroviral vectors & $\begin{array}{l}\text { CD4-specific transduction of HIV-I } \\
\text { genes: env, vpu, tat, and rev }\end{array}$ & $\begin{array}{l}\text { Induction of humoral and cellular anti- } \\
\text { HIV-I responses in vivo }\end{array}$ & 96,97 \\
\hline Rabies virus & Attenuated RV-expressing SIV-I proteins & $\begin{array}{l}\mathrm{SIV}_{\text {MAC }} \text {-challenged macaques expressed } \\
\text { higher antibody and CTL responses } \\
\text { than nonvaccinated controls }\end{array}$ & 98,99 \\
\hline Alphavirus & $\begin{array}{l}\text { HIV-I strain R2 env expression } \\
\text { followed by administration of } \\
\text { soluble oligomeric gP I } 20\end{array}$ & $\begin{array}{l}\text { Induction of humoral and cell-mediated } \\
\text { responses that were protective against } \\
\text { heterologous HIV challenges in rhesus } \\
\text { macaques }\end{array}$ & 100 \\
\hline Canarypox & $\begin{array}{l}\text { Prime with ALVAC-HIV (vCPI52I) } \\
\text { boost with AIDSVAX B/E }\end{array}$ & $\begin{array}{l}\text { Inhibition of infection noted in vaccinees, } \\
\text { although viremia was not reduced in those } \\
\text { vaccinees that did become infected }\end{array}$ & 101 \\
\hline Adeno-associated viruses & $\begin{array}{l}\text { Gene transfer in muscle of antibodies } \\
\text { or antibody-like immunoadhesins }\end{array}$ & $\begin{array}{l}\text { Long-lasting neutralizing activity in serum } \\
\text { of monkeys against SIV }\end{array}$ & 102 \\
\hline Ads & Vaccination with a recombinant Ad5 construct & $\begin{array}{l}\text { Induction of humoral and cellular responses } \\
\text { in mice, dogs, chimpanzees, or nonhuman } \\
\text { primates }\end{array}$ & $103-106$ \\
\hline \multicolumn{4}{|l|}{ Other } \\
\hline Virus cocktails & $\begin{array}{l}\text { HIV-I vaccination with successive immunizations } \\
\text { containing recombinant DNA, recombinant } \\
\text { vaccinia virus, and recombinant env proteins }\end{array}$ & $\begin{array}{l}\text { Following challenge with SHIV strains that } \\
\text { were not used in vaccination cocktail, four of } \\
\text { six vaccinated macaques lived through the } \\
44 \text {-week observation period as compared } \\
\text { to one of six control macaques }\end{array}$ & 107 \\
\hline Fibroblasts & $\begin{array}{l}\text { Immunization with retroviral vector-transduced } \\
\text { fibroblasts expressing human immunodeficiency } \\
\text { virus type-I IIIB ENV/REV proteins }\end{array}$ & $\begin{array}{l}\text { Induction of CTL and antibody responses } \\
\text { in rhesus monkeys }\end{array}$ & 108 \\
\hline Dendritic cell-based vaccines & $\begin{array}{l}\text { Immunization with retroviral-vector transduced } \\
\text { dendritic cells }\end{array}$ & $\begin{array}{l}\text { Induction of CTL and antibody responses } \\
\text { in cynomolgus monkeys }\end{array}$ & 109 \\
\hline Virus-like particles & $\begin{array}{l}\text { Goal - present artificially produced partial HIV-I } \\
\text { proteins in order to stimulate Nabs }\end{array}$ & $\begin{array}{l}\text { Humoral and cellular response } \\
\text { achieved in mice or rabbits }\end{array}$ & $110-114$ \\
\hline
\end{tabular}

Note: aProof of principle studies using SIV or FIV.

Abbreviation: CTL, cytotoxic T-lymphocyte. 
plasmids coding for cytokines (eg, INF-g, IL-2, IL-12, IL-18, and IL-15). ${ }^{121-124} \mathrm{~A}$ second strategy which has been utilized to improve plasmid DNA vaccination has been the administration of plasmid DNA with adjuvants (eg, CpG oligodeoxynucleotides), or the use of DNA-delivery systems (eg, microparticles, cochleates, and linear polyenimines). ${ }^{125-128}$ A third strategy to improve vaccine efficacy involves the coadministration of plasmid DNA in combination with viral vectors. For instance, research performed by Harari and colleagues in 2008 demonstrated that vaccination by means of an HIV-1 clade C DNA prime in combination with a pox vector (NYVAC) boost induces a reliable polyfunctional and longlasting anti-HIV T-cell response in human participants. ${ }^{129}$ Along these same lines, work recently published by Jaoko and group demonstrated safety and immunogenicity of a multiclade HIV-1 Ad-based vaccine alone or in combination with a multiclade HIV-1 DNA vaccine in Africa. These results also demonstrated that DNA priming increased the frequency and magnitude of cellular and humoral responses; however, there was no effect of recombinant Ad5 dosage on immunogenicity endpoints. ${ }^{130}$

The previously mentioned DNA-delivery strategies have been used in combination with viral vectors or alone by means of a variety of immunization routes (eg, IM, intravenous [IV], intradermal [ID], intranasal [IN], oral, rectal, or vaginal). In the majority of reported studies, DNA vaccines have been administered by the IM and/or ID routes. However, as it relates to HIV vaccination, mucosal immunity could potentially be an important factor to consider, with mucosal immunity being achieved optimally by IN or oral routes of administration. The topic of mucosal immunity will be discussed in more detail in a later section within this review.

After immunization, it is assumed that the DNA vaccination immunogen is produced in the skeletal muscles, dendritic cells, and macrophages at the site of immunization. However, in adults, the skeletal muscles are not involved in a high level of protein synthesis as compared to the liver. Therefore, the delivery of DNA to cells, which are capable of high protein synthesis, such as hepatocytes, epithelia cells of the intestines, or salivary pancreas, may result in high levels of protein expression. The hepatocytes express enzymes involved in the formation of intrachain and interchain disulfide bonds required for proper folding and assembly of proteins. In addition, the liver expresses glycosyltranferases, which are essential for synthesis of both $N$ - and $O$-linked glycan side chains; this may not be the case for other cell types, ${ }^{131,132}$ the significance of this point being the fact that broadly crossclade Nabs such as 2 G12 recognize glycan moieties on the heavily glycosylated HIV-1 envelope antigens. ${ }^{44,133,134}$ Another advantage of protein expression within the liver is that significantly lower amounts of DNA are needed for protein expression of a particular antigen in the hepatocytes vs another cell type. For the immunization of humans, milligram quantities of DNA are necessary to achieve adequate levels of immune response. ${ }^{119}$ Any method whereby there would be a reduction in DNA quantity needed to vaccinate humans would provide significant economic advantages. Based on the previously mentioned reasons, it is not a surprise that the liver has been exploited extensively as a site for gene delivery due to its ability to produce proteins and glycoproteins. ${ }^{135-138}$

Hydrodynamic delivery is the application of controlled hydrodynamic pressure in capillaries to enhance endothelial and parenchymal cell permeability; this methodology had its inception in the late 1990 s with investigations into intravascular injection of plasmid DNA solution for gene delivery in whole animals. ${ }^{139-142}$ Hydrodynamic plasmid DNA delivery is well tolerated in mice. In 2008, Raska and colleagues demonstrated in mice that IV hydrodynamic vaccination with HIV-1 envelope DNA injections resulted in high levels of expression of HIV antigen in the liver. In mice, immunological data illustrated that hydrodynamic administration of HIV-1 plasmid DNA was superior to vaccination with DNA by IN, ID, IM, and intrasplenic routes. Further results illustrated that after boosting, hydrodynamic vaccination yielded levels of HIV-1-specific antibodies that were 40-fold higher than those elicited by other routes tested. ${ }^{132}$

However, this delivery scheme is not feasible in large animals and humans. As an alternative, receptor-mediated DNA binding to hepatocytes could be a viable approach. Molecules with terminal galactose residues covalently linked to DNA are recognized by the hepatocyte-expressed galactosespecific asialoglycoprotein ${ }^{143}$ receptor for internalization. ${ }^{144}$ This alternative would avoid delivery through the hepatic system and the need for expansion of the blood volume. In addition, galactose-linked DNA packaged in delivery vehicles such as liposomes, choleates, or microspheres can be given by oral administration, which would be absorbed by the intestine and ultimately delivered to the hepatic vein. As an additional alternative to hydrodynamic delivery in humans, it might be possible to express HIV antigens in the liver by means of plasmid DNA delivery via viral vectors such as the Ad. Ads have been shown to transduce the liver efficiently in vivo by means of the hexon proteins. ${ }^{145,146}$ In this regard, production of translation of HIV-1 proteins primarily in the liver might allow for the production of heavily glycosylated HIV-1 envelope antigens and thus the production of Nabs. 


\section{Live recombinant vectors for vaccine development}

Viral vectors are potent inducers of cellular and humoral response. Viral vectors can express proteins from bacteria or viral pathogens to vaccinate against infectious diseases. There are several viral vaccine vectors that have been used successfully in models for vaccination. These vectors include alphaviruses, human rhinoviruses (HRVs), Ads, picornaviruses, poxviruses, measles viruses, influenza, and vaccinia viruses. ${ }^{30,129,147-156}$ Each of these vectors has its respective disadvantages and advantages with respect to vaccine development. Some advantages of a few of these vectors include their ability to naturally infect a wide variety of cell types and tissues of interest. ${ }^{157-162}$ Each respective vector has its own set of disadvantages. For instance, one disadvantage of using the poliovirus or the HRV as a vaccine vector is the insert size limit restriction of these vectors as compared to the large insert size $(\sim 8 \mathrm{~kb})$ accommodation of Ad vectors.

The most common disadvantage of the majority of viral vaccine vectors is reduced vaccine efficacy due to vector preexisting immunity (PEI). ${ }^{163-167}$ Various strategies have been employed to circumvent the problems associated with vector PEI. Specifically, as it relates to Ad vectors, PEI is a tremendous problem. Of the identified serotypes of Ad vectors, human serotypes 5 (Ad5) and $2(\operatorname{Ad} 2)$ have been the most extensively used for gene therapy protocols. Ad5 has been used for HIV-1 vaccination protocols, most recently in the STEP study. As it relates to Ad2 and Ad5, PEI to these vectors may be found in up to $50 \%$ of the American population and up to $95 \%$ of the population of other countries. This Ad PEI can limit the effectiveness of Ad-based vaccinations. ${ }^{168-170} \mathrm{To}$ circumvent Ad2 or Ad5 PEI, researchers have employed the use of vector chimeras, ${ }^{166,171}$ use of alternative serotypes, ${ }^{172-178}$ and the use of nonhuman Ads, ${ }^{151}$ such as chimpanzee Ad. The chimpanzee Ad virus was demonstrated to not be significantly neutralized by human sera, which gives chimpanzee Ad an advantage for human vaccine development. ${ }^{179-181}$

Other strategies have been used to reduce the immune response against Ad vectors such as the use of helperdependent Ad (HD-Ads) vectors, ${ }^{182-187}$ the use of Ad delivery in combination with biochemical modifications such as PEGylation, ${ }^{188-194}$ and the use of vector delivery by means of cell vehicles. ${ }^{195,196}$ With respect to the HD-Ads, these vectors were produced to further increase the safety and cloning capacity of first-generation Ad vectors. HD-Ads lack Ad genes and contain only the packaging signals and end terminal repeats. These vectors were designed to avoid cellular immunity and diminish liver toxicity, thus promoting long-term transgene expression. ${ }^{197-200}$ The reduced immune response against HD-Ads has allowed for transgene expression in mice and baboons for years. ${ }^{182,183,185,200}$ This long-term transgene expression could be helpful for antigen production for an HIV vaccine, thus producing an opportunity to have increased protection against HIV, with reduced frequency of vaccinations.

Although Nabs to Ad5 may reduce the immunogenicity of Ad5-based vectors in animal model systems, their effect on the immunity in subjects with previous Ad5 exposure is still largely unknown. As previously mentioned, the STEP trial, which tested a Merck recombinant Ad5 (rAd5) vaccine (encoding HIV-1 gag, pol, and nel genes), failed to yield protection, either by lowering viral load or by decreasing acquisition of infection. ${ }^{13}$ Analysis of data from this study aroused speculation that subjects with pre-existing Nabs from wild-type Ad5 infection had an increased risk of HIV infection after vaccination. One recent study has shown that there was no causative role for $\mathrm{Ad} 5$-specific $\mathrm{CD} 4^{+} \mathrm{T}$ cells in increasing HIV-1 susceptibility in the Merck trial. ${ }^{201}$ In this regard, there are multiple studies ongoing to elucidate a concrete finding with respect to the role of Ad5 PEI and increased activation of $\mathrm{CD}^{+} \mathrm{T}$ cells in the mucosal milieu. ${ }^{202,203}$

Recently, there was a report by Cheng and colleagues that attempted to characterize the specificity of rAd5 Nabs in Ad5immune subjects and determine the impact of Ad exposure on immune responses elicited by Ad5-based vaccinations. Cheng and colleagues reported that $\mathrm{rAd} 5 \mathrm{Nabs}$ were directed toward different components of the Ad virion, depending on whether the Ad5 infection was natural or from Ad-based HIV vaccine trials. For example, Ad Nabs generated by natural infection are directed primarily to fiber components, while vector exposure elicits responses primarily to capsid proteins other than fiber. Nabs elicited by natural infection significantly reduced the $\mathrm{CD} 8^{+}$and $\mathrm{CD} 4^{+}$cell responses to HIV Gag after DNA/rAd5 vaccination. This report concluded that Ad5 Nabs differ based on the route of exposure and that previous Ad5 exposure compromises Ad5 vaccine-induced immunity to weak immunogens, such as HIV-1 Gag. ${ }^{204}$ These results have a tremendous impact on HIV-1 vaccine trials and the design of next generation viral vaccine vectors.

Viral vectors such as Ad, influenza, and polio have been used as vaccine vectors for many reasons. One important advantage of these vectors, which makes them attractive, is that they can provide mucosal immunity because they can easily infect the mucosal surfaces as well as act to induce cytokine and chemokine production at the mucosal entry sites. Ad, influenza, and polio also have the advantage of 
being able to be delivered orally, without the use of needles. This is an important fact in developing countries where needle cost is prohibitive to vaccine administration. As it relates to HIV vaccine development, mucosal immunity is a debatable factor to consider.

\section{Mucosal HIV immunity}

When deciding upon a vaccine agent, the importance of considering if the ultimate goal is to induce systemic immunity, mucosal immunity, or both is worth careful consideration. ${ }^{205-207}$ It is believed that $80 \%$ of HIV-1 infection will occur from heterosexual viral transmission and most of the rest will occur from homosexual or perinatal transmission. ${ }^{152}$ Although the biology of sexual transmission is poorly understood, it is clear that the essential first step in the infection pathway is the transfer of infectious virus or HIV-infected cells through the mucosal surfaces. After HIV has entered a new host, the HIV or HIV-infected cells will soon encounter susceptible host target cells at the mucosal point of entry where the virus replicates and then invades local lymphatic tissues, initiating systemic HIV infection. On this basis, strong immunity is required to provide a protective immunological barrier at the most common point of entry, the mucosal surfaces of the reproductive tract. Due to the compartmentalization of the secretory and systemic immune systems, parenterally administered antigens do not consistently stimulate mucosal immunity. ${ }^{152}$ Therefore, it is important to consider a vaccine regime that induces mucosal immunity.

Since $\mathrm{CD}^{+} \mathrm{CCR}^{+}$memory $\mathrm{T}$ cells are the primary target of HIV infection in the gut and mucosa and rapid depletion of this subset occurs early after infection, ${ }^{208,209}$ several studies have investigated the role of HIV mucosal immunity. Previous studies have demonstrated the importance of a mucosal SIV/HIV vaccine producing both strong mucosal antibody and $\mathrm{CD}^{+}$response capable of blocking the escape of virus from the intestinal mucosa into systemic lymphoid organs. ${ }^{207,210-214}$ However, in other instances, the necessity of exclusive mucosal HIV immunity will be further debated based on the promising results found in a heterologous prime/boost regimen using DNA/89.6-expressing SIV and HIV-1 transcripts ${ }^{215,216}$ and modified vaccinia virus Ankara (MVA/89.6)-expressing SIV and HIV-1 transcripts under the control of vaccinia virus early/late promoter. In this case, either ID or IM DNA/MVA vaccination was able to provide protection against a intrarectal SHIV-89.6 challenge. ${ }^{153}$ Along these same lines, recently, promising results were found by Hessell and colleagues in 2010. Hessell and colleagues demonstrated that after an IV administration of monoclonal antibodies 2F5 or 4E10 to six monkeys followed by a $\mathrm{SHIV}_{\text {ba-L }}$ challenge, five out of six monkeys from either group showed complete protection and sterilizing immunity. A low level of viral replication could not be ruled out for the six monkeys in either group. ${ }^{217}$

Replicative Ad yields a robust immune response at the mucosal sites partly because Ad is known to infect and replicate in epithelial cells. ${ }^{218-221}$ Various strategies have been used to achieve mucosal immunity via the oral route. One such strategy embodies the development of replication-defective recombinant Ad serotype 41 (Ad41) vector. ${ }^{222}$ Serotype 41 vectors are being currently used because Ad41 has a natural tropism for the gut and causes no pathological disease outside of the gastrointestinal tract. ${ }^{223}$ Ad41 vectors are likely to have a preferential tropism for the gut because Ad41 appears to have a resistance to acidic $\mathrm{pH}^{224}$ and the capsid configuration of long and short fibers allows the Ad41 virus to preferentially infect the gut. ${ }^{177,225}$

\section{Live recombinant vectors for vaccine development engineered to express/present HIV-I antigens}

As previously mentioned, viral vectors are potent inducers of cellular and humoral responses. Of note, viral vectors have been practically used for human applications and have progressed treating a variety of disease contexts such as cancer and infectious diseases. ${ }^{226-229}$ Traditional viral vector immunization embodies the concept that the vector uses the host cell machinery to express antigens, which are encoded as transgenes within the viral vector. Cellular and humoral immune responses are generated against these antigens. Over the last 20 years, several viral vectors have been derived to express HIV-1 antigens for vaccine purposes.

Some researchers have taken an alternative approach to conventional transgene expression of antigens by means of viral vectors; this alternative approach embodies the capsid incorporation of antigens. This innovative paradigm is based upon the vector presenting the antigen as a component of the capsid rather than an encoded transgene. Incorporation of immunogenic peptides into the vector capsid offers potential advantages. In this regard, the processing of the capsidincorporated antigen via the exogenous pathway should result in a strong humoral response similar to the response provoked by native Ad capsid proteins. In this arrangement, potentially, HIV peptide antigens accrue the potent immunostimulatory effects of the native Ad vector capsid proteins, which effectively perform an adjuvant function. On this basis, the immune response directed against vector 
capsid proteins with repetitive vector administration should achieve a booster effect against the incorporated antigen. ${ }^{230}$ Most importantly, as it relates to HIV infection, this strategy yields the potential of generating antibodies to HIV proteins. Recent crystallographic, cryo-electron tomography, and molecular modeling studies have provided valuable insight to molecular surfaces recognized by antibodies as well as assisted in rationale vaccine design of immunogens. ${ }^{231-235}$ These structural technologies can also potentially improve the abilities of scientists to advance the antigen capsidincorporation strategy. If the antigen capsid incorporation is effective, it can provide a way forward with respect to inducing sterilizing immunity. ${ }^{68,236,237}$

The antigen capsid-incorporation strategy has been used for Ad-based vaccines in the context of many diseases. ${ }^{230,238-242}$ One of the first examples where the antigen capsid-incorporation strategy was used was with research performed by Crompton in $1994 .{ }^{242}$ Crompton and colleagues inserted an eight-amino acid sequence of the VP1 capsid protein of poliovirus type 3 into two regions of the Ad2 serotype hexon. One of the chimeric vectors produced grew well in tissue culture. In addition, antiserum raised against the Ad with the polio insert specifically recognized the VP1 capsid of polio type 3 . As it relates to Ad5 serotype, Wu and group demonstrated that $\mathrm{His}_{6}$ epitopes could be incorporated into Ad hexon hypervariable regions (HVRs) 1-7 (now reclassified as 1-9) without perturbing viral viability and any major biological characteristics such as replication, thermostability, or native infectivity. This study by Wu and colleagues demonstrated that $\mathrm{His}_{6}$ appeared to be surface exposed at these regions. ${ }^{243}$ With respect to peptide incorporation within Ad5 hexon, HVR2 and HVR5 appear to be the most promising locales for peptide/antigen incorporation based on X-ray and peptide analyses along with molecular studies. ${ }^{244}$ Our laboratory and others have focused on incorporations at HVR5 or single-site incorporations (such as fiber and pIX). ${ }^{230,238-241-}$ ,243,245,246 However, we recognized that the ability to place antigen within multiple sites of the Ad capsid protein would hold important potential for presenting multiple epitopes/ antigens or several copies of the same epitope within a single Ad vector-based vaccine.

In an effort to create multivalent HIV vaccine vectors, our 2008 study explored the use of Ad5 HVR2 and HVR5 in hopes of creating vectors which contained HIV antigenic epitopes at both locales. To compare the flexibility and capacities of Ad5 HVR2 and HVR5, we genetically incorporated identical epitopes of incrementally increasing size within HVR2 or HVR5 of Ad5 hexon. We incorporated identical epitopes ranging from 33 to 83 amino acids within the Ad5 hexon HVR2 or HVR5 region. Viable viruses were produced with incorporations of 33 amino acids plus a 12-amino acid linker at HVR2 or HVR5. In addition, viable viruses were produced with incorporations of up to 53 amino acids plus a 12-amino acid linker at HVR5. With respect to identical antigen incorporations at Ad5 HVR2 or HVR5, HVR5 was more permissive allowing an epitope incorporation of 65 amino acids in total. These model antigens were surface exposed via ELISA analysis. In vivo immunization with these vectors illustrated an antigen-specific immune response. ${ }^{240}$

Along these same lines, Abe and colleagues evaluated the ability of Ad5-based vectors expressing an HIV transgene to induce antigen-specific immune responses under Ad5 preimmune conditions. To overcome limitations that are generally experienced as a result of PEI to Ad5, they constructed vectors that have a modification in the HVR5. Their study characterized various immunological parameters generated by these vectors such as vector neutralization, acquisition of adaptive immune response, and comparison of protective immunity. First, in order to evaluate the utility of the modified Ad vector, they measured the neutralizing activity of sera by a modified Ad vector. They administered Ad-Luc (luciferase protein expressed as a transgene in the Ad E1 region), Ad-HisLuc (His ${ }_{6}$ epitope presented in HVR5 region and luciferase protein expressed as a transgene), or Ad-END/ AAALuc vector (containing three amino acid mutations in HVR5 and expressing luciferase protein) to mice IM. After administration of these vectors, neutralizing activity against Ad5 was observed for $0-8$ weeks. The hexon-modified vector (Ad-HisLuc) generated the lowest Ad5-specific neutralizing activity, which was significantly lower than what was generated by Ad-Luc at weeks 6 and 8, and by Ad-End/AAALuc vector at week 8 . The individual neutralizing activity of Ad-HisLuc immunization was significantly lower than that of Ad-Luc immunization. Additional studies performed by Abe and colleagues support the concept that modified hexon thwarts Ad5 Nabs and promotes cellular immune responses. ${ }^{247}$ Studies performed by this research group indicate that a change in the immunogenic epitope is necessary to avoid neutralization by pre-existing Nabs.

Our recently published work exploits the antigen capsidincorporation strategy for HIV vaccination. Our novel vectors were constructed in hopes of moving toward the goal of creating vectors that will provide cellular and humoral HIV immunity. Our study is the first of its kind to genetically incorporate an HIV antigen within the Ad5 hexon HVR2 alone or in combination with genomic incorporation of a 
Gag transgene (Ad5/HVR2-MPER-L15(Gag)). In this study, we successfully incorporated a 24-amino acid epitope of HIV-1 within HVR2. The HIV-1 region selected for HVR2 incorporation was the membrane proximal ectodomain region (MPER) derived from HIV-1 glycoprotein 41 (gp41). Our rationale for choosing a portion of the MPER (EKNEKELLELDKWASLWNWFDITN) derived from gp41 was based on the fact that the gp41 envelope protein ectodomain is a target of three broadly neutralizing anti-HIV-1 antibodies. ${ }^{248}$ When the MPER was incorporated into HVR2 in combination with transgene expression, we observed growth kinetics and thermostability changes similar to those of other capsid-incorporated vectors generated in other studies, ${ }^{249,250}$ indicating that incorporation of the MPER epitope within HVR2 was not dramatically detrimental to virological characteristics. ${ }^{250,251}$ In addition, we demonstrated that the MPER epitope is surface exposed within HVR2. Most importantly, we observed a humoral anti-HIV response in mice vaccinated with the hexon-modified vector. The MPER-modified vector allows boosting compared to AdCMVGag, possibly because the Ad5/HVR2-MPER-L15(Gag) Ad elicits less antiAd5 immune response. It is possible that the MPER epitope reduced the immunogenicity of the Ad5 vector. This finding is noteworthy because HVR2 has not been fully explored for antigen capsid-incorporation strategies. ${ }^{252}$ These vectors are currently being analyzed by cryo-electron microscopic analysis to determine the critical correlates related to antigen placement/configuration and immune response.

In addition, with respect to HIV-1 vaccination, the antigen capsid-incorporation strategy has been evaluated within the context of HRV. Research groups have constructed human rhinovirus:HIV-1 chimeras in an effort to stimulate immunity against HIV-1. ${ }^{148,253}$ In an effort to develop HIV-1 vaccines, researchers within this same group generated combinatorial libraries of HRV capsid-incorporated HIV-1 gp41 epitope. Their results indicated that they were successful in eliciting antibodies whose activity can mimic the Nab effect. ${ }^{149}$

Commercial and clinical Ad development of HIV-1 vaccines have progressed preferentially more than vector systems such as HRV because the flexibility of Ad generally exceeds current rhinovirus systems. For example, because HRV is a relatively small RNA virus, the HRV platform can display an array limited to 60 copies of a single HIV-1 epitope. ${ }^{148,253}$ In contrast, the Ad vector platform allows incorporation of the HIV-1 MPER epitope into three structurally distinct locales, including HVR2, HVR5, ${ }^{247}$ and protein IX (our unpublished data). In comparison, the Ad MPER antigen capsid-incorporation display platform could present an array of $720 \mathrm{HIV}-1$ epitope copies within Ad hexon and 240 HIV-1 epitope copies within pIX. If a multivalent Ad vector is generated with HIV-1 epitopes within the hexon and the pIX locales, this would represent 960 HIV epitopes within one Ad vector. Another significant difference between the Ad and HRV platforms is in the number of locales that have been successfully used for heterologous epitope insertion. Finally, in contrast to the rhinovirus that lacks this capacity, the Ad platform has sufficient coding capacity allowing for HIV-1 transgene expression in combination with presenting the same or a different antigen on the viral capsid surface. This latter finding is important because it provides the basis for constructing vectors that will provide cellular and humoral HIV-1 immunity. Vectors which provide both cellular and humoral immunity may be the way forward with respect to prophylactic HIV vaccine development.

\section{Promising results in an effort to produce an HIV vaccine}

Recently, there have been encouraging developments regarding HIV vaccination. In the 1980 s, in Thailand, there was a substantial increase in the prevalence of infection with HIV-1. ${ }^{254-256}$ By first observation, these groups consisted of intravenous-drug users and commercial sex workers; this infected group then expanded to the general population. ${ }^{101} \mathrm{By}$ the mid 1990s, the overall seroprevalence of HIV-1 reached a peak of $3.7 \%$ among members of the Royal Thai Army and of $12.5 \%$ among people from Northern Thailand. ${ }^{255,257}$ The Thai Ministry of Public Health acted by starting an effective HIV-prevention campaign. With this effort, the number of new HIV-1 infections per year decreased from an estimated 143,000 in 1990 to 14,000 in $2007 . .^{255,258-260}$ Although this decrease was promising, there was still a desire to do more to prevent HIV infection. To achieve this goal, an HIV Phase III study was begun.

The Thai Phase III HIV vaccine study, also known as RV144, opened in the fall of 2003. The placebo-controlled trial tested the safety and effectiveness of a prime-boost regimen of two vaccines: ALVAC-HIV vaccine (the prime), a modified canarypox vaccine, and AIDSVAX B/E vaccine (booster), a gp 120 vaccine. The vaccines were based on the subtype E and B HIV-1 strains that commonly circulate in Thailand. The subtype B HIV-1 strain is the most commonly found strain in the United States. The trial, conducted in the Chonburi and Rayong provinces of Thailand, enrolled 16,402 women and men aged 18-30 years at various levels of risk for HIV infection. Study participants received the placebo or ALVAC HIV vaccine at enrollment and again after 1, 3, 
and 6 months. The placebo or AIDSVAX B/E vaccine was given to participants at 3 and 6 months. Participants were tested for HIV-1 infection every 6 months for 3 years. During each clinic visit, study participants were counseled on how to prevent HIV-1 infection.

The results showed that 74 of 8198 placebo recipients became infected with HIV-1 compared with 51 of 8197 participants who received the vaccine. This level of effectiveness in preventing HIV-1 infection was found to be statistically significant. The vaccine strategy had no effect, however, on the amount of virus in the blood of volunteers who acquired HIV-1 infection during the study. Based on the final analysis of the study, the surgeon general of the US Army, the trial sponsor, announced that the prime-boost investigational vaccine regimen was safe and $31 \%$ effective in preventing HIV-1 infection. With respect to an HIV-1 vaccine that can provide sterilizing HIV immunity, this is the best result in humans to date. However, the modest protection effect appeared limited to low-risk individuals, and there were data which suggest that this effect was confined to the first year following administration of the vaccine. Efforts must continue to focus on evaluating the immune response induced by the vaccine to establish potential correlates of protection.

\section{Conclusion}

Over the last three decades, the world has been faced with the emergence and subsequent epidemic of HIV/AIDS. There has been much progress with respect to diagnosis and prevention. On the treatment front, there have been several significant advances with respect to drug development (ie, ART/HAART). However, there is a desperate need for an effective and safe vaccine. There has been tremendous difficulty with regard to developing a vaccine that provides sterilizing immunity. This has been the case due to some of the factors mentioned in this review such as HIV diversity, immune evasion, and lack of appropriate animal models. Due to these obstacles, many researchers assumed that the control of HIV-1 viremia by vaccination would be a more realistic goal than the development of sterilizing immunity.

The road to a safe and effective HIV-1 vaccine received a serious setback in the fall of 2007 with the premature termination of the Merck-HIV-1 Vaccine STEP trial due to the lack of efficacy and early speculation that the vaccine might have increased the risk of HIV infection in some populations of vaccinees. In late 2009, promising results came in from Thailand in response to their efforts to create a safe and effective vaccine against HIV-1. A community-based, randomized, multicenter, double-blinded, placebo-controlled efficacy trial using a prime-boost combination showed $31 \%$ effectiveness in preventing HIV-1 infection. These results lend promise to the hope of producing an HIV-1 vaccine vector that yields sterilizing HIV-1 immunity.

In the future, research scientists must work together to increase HIV-1 vaccine effectiveness beyond 31\%. Realization of this goal may be accomplished by some of the techniques mentioned in this review, such as acquisition of HIV mucosal immunity, development of effective prime-boost strategies, development of better animal models, better molecular antigen modeling and presentation, avoidance of PEI (by the means of using novel vector serotypes in combination with PEGylation), and/or induction of Nabs (by means of capsid incorporation of HIV antigens within viral vectors). These are just a few considerations that scientists and clinicians must consider with respect to the development of an effective and safe HIV-1 vaccine. Scientists and clinicians must also consider that one vector or scheme may not be sufficient with respect to providing effective HIV-1 immunity and some combination of the above-mentioned potential strategies may offer the most promising method of producing an effective HIV-1 prophylactic vaccine.

\section{Acknowledgments}

Grant support was provided by National Institutes of Health grants 1R33AI076096-01, 2P30AI027767-21A1, and 3P30CA013148-38S9. We thank Erin E Thacker for her thoughtful insight.

\section{Disclosure}

The authors report no conflicts of interest in this work.

\section{References}

1. UNAIDS. 2008 Report on the Global AIDS Epidemic. 2010. Available from: http://www.unaids.org/en/KnowledgeCentre/HIVData/ GlobalReport/2008/2008_Global_report.asp. Accessed 2010 Oct 3.

2. Duggan JM, Locher A, Fink B, Okonta C, Chakraborty J. Adherence to antiretroviral therapy: a survey of factors associated with medication usage. AIDS Care. 2009;21(9):1141-1147.

3. Thiebaut R, Daucourt V, Mercie P, et al. Lipodystrophy, metabolic disorders, and human immunodeficiency virus infection: Aquitaine Cohort, France, 1999. Groupe d'Epidemiologie Clinique du Syndrome d'Immunodeficience Acquise en Aquitaine. Clin Infect Dis. 2000;31(6): $1482-1487$.

4. Carr A, Miller J, Law M, Cooper DA. A syndrome of lipoatrophy, lactic acidaemia and liver dysfunction associated with HIV nucleoside analogue therapy: contribution to protease inhibitor-related lipodystrophy syndrome. AIDS. 2000;14(3):F25-F32.

5. Mondy K, Yarasheski K, Powderly WG, et al. Longitudinal evolution of bone mineral density and bone markers in human immunodeficiency virus-infected individuals. Clin Infect Dis. 2003;36(4) 482-490.

6. Noe A, Plum J, Verhofstede C. The latent HIV-1 reservoir in patients undergoing HAART: an archive of pre-HAART drug resistance. J Antimicrob Chemother. 2005;55(4):410-412. 
7. Shacklett BL. Mucosal immunity to HIV: a review of recent literature. Curr Opin HIV AIDS. 2008;3(5):541-547.

8. Burton DR, Desrosiers RC, Doms RW, et al. HIV vaccine design and the neutralizing antibody problem. Nat Immunol. 2004;5(3):233-236.

9. McMichael AJ. HIV vaccines. Аnпи Rev Immunol. 2006;24:227-255.

10. Emini EA, Koff WC. AIDS/HIV. Developing an AIDS vaccine: need, uncertainty, hope. Science. 2004;304(5679):1913-1914.

11. Thorner AR, Barouch DH. HIV-1 vaccine development: progress and prospects. Curr Infect Dis Rep. 2007;9(1):71-75.

12. Robinson HL, Amara RR. T cell vaccines for microbial infections. Nat Med. 2005;11 Suppl 4:S25-S32.

13. Sekaly RP. The failed HIV Merck vaccine study: a step back or a launching point for future vaccine development? J Exp Med. 2008; 205(1):7-12.

14. Almond N, Kent K, Cranage M, Rud E, Clarke B, Stott EJ. Protection by attenuated simian immunodeficiency virus in macaques against challenge with virus-infected cells. Lancet. 1995;345(8961):1342-1344.

15. Stahl-Hennig C, Dittmer U, Nisslein T, et al. Rapid development of vaccine protection in macaques by live-attenuated simian immunodeficiency virus. J Gen Virol. 1996;77(Pt 12):2969-2981.

16. Learmont J, Tindall B, Evans L, et al. Long-term symptomless HIV-1 infection in recipients of blood products from a single donor. Lancet. 1992;340(8824):863-867.

17. Berkhout B, Verhoef K, van Wamel JL, Back NK. Genetic instability of live, attenuated human immunodeficiency virus type 1 vaccine strains. J Virol. 1999;73(2):1138-1145.

18. Learmont J, Cook L, Dunckley H, Sullivan JS. Update on long-term symptomless HIV type 1 infection in recipients of blood products from a single donor. AIDS Res Hum Retroviruses. 1995;11(1):1.

19. Duerr A, Wasserheit JN, Corey L. HIV vaccines: new frontiers in vaccine development. Clin Infect Dis. 2006;43(4):500-511.

20. Flynn NM, Forthal DN, Harro CD, Judson FN, Mayer KH, Para MF. Placebo-controlled phase 3 trial of a recombinant glycoprotein 120 vaccine to prevent HIV-1 infection. J Infect Dis. 2005;191(5): 654-665.

21. Gilbert PB, Peterson ML, Follmann D, et al. Correlation between immunologic responses to a recombinant glycoprotein 120 vaccine and incidence of HIV-1 infection in a phase 3 HIV-1 preventive vaccine trial. J Infect Dis. 2005;191(5):666-677.

22. Graham BS, Mascola JR. Lessons from failure - preparing for future HIV-1 vaccine efficacy trials. $J$ Infect Dis. 2005;191(5):647-649.

23. Pitisuttithum P, Gilbert P, Gurwith M, et al. Randomized, double-blind, placebo-controlled efficacy trial of a bivalent recombinant glycoprotein 120 HIV-1 vaccine among injection drug users in Bangkok, Thailand. J Infect Dis. 2006;194(12):1661-1671.

24. Hemelaar J, Gouws E, Ghys PD, Osmanov S. Global and regional distribution of HIV-1 genetic subtypes and recombinants in 2004. AIDS. 2006;20(16):W13-W23.

25. Plantier JC, Leoz M, Dickerson JE, et al. A new human immunodeficiency virus derived from gorillas. Nat Med. 2009;15(8):871-872.

26. Renjifo B, Gilbert P, Chaplin B, et al. Preferential in-utero transmission of HIV-1 subtype $\mathrm{C}$ as compared to HIV-1 subtype A or D. AIDS. 2004;18(12):1629-1636.

27. Bhoopat L, Rithaporn TS, Khunamornpong S, Bhoopat T, Taylor CR, Thorner PS. Cell reservoirs in lymph nodes infected with HIV-1 subtype E differ from subtype B: identification by combined in situ polymerase chain reaction and immunohistochemistry. Mod Pathol. 2006;19(2):255-263.

28. Vasan A, Renjifo B, Hertzmark E, et al. Different rates of disease progression of HIV type 1 infection in Tanzania based on infecting subtype. Clin Infect Dis. 2006;42(6):843-852.

29. Kaleebu P, Nankya IL, Yirrell DL, et al. Relation between chemokine receptor use, disease stage, and HIV-1 subtypes A and D: results from a rural Ugandan cohort. J Acquir Immune Defic Syndr. 2007;45(1):28-33.

30. Cohen J. HIV. Escape artist par excellence. Science. 2003;299(5612): $1505-1508$.
31. Moore JP, Parren PW, Burton DR. Genetic subtypes, humoral immunity, and human immunodeficiency virus type 1 vaccine development. J Virol. 2001;75(13):5721-5729.

32. McBurney SP, Ross TM. Viral sequence diversity: challenges for AIDS vaccine designs. Expert Rev Vaccines. 2008;7(9):1405-1417.

33. Seaman MS, Leblanc DF, Grandpre LE, et al. Standardized assessment of NAb responses elicited in rhesus monkeys immunized with single- or multi-clade HIV-1 envelope immunogens. Virology. 2007;367(1):175-186.

34. Kibuuka H, Kimutai R, Maboko L, et al. A phase 1/2 study of a multiclade HIV-1 DNA plasmid prime and recombinant adenovirus serotype 5 boost vaccine in HIV-Uninfected East Africans (RV 172). $J$ Infect Dis. 2010;201(4):600-607.

35. Santra S, Liao HX, Zhang R, et al. Mosaic vaccines elicit CD8(+) T lymphocyte responses that confer enhanced immune coverage of diverse HIV strains in monkeys. Nat Med. 2010;16(3):324-328.

36. Corey L, McElrath MJ. HIV vaccines: mosaic approach to virus diversity. Nat Med. 2010;16(3):268-270.

37. Barouch DH, O'Brien KL, Simmons NL, et al. Mosaic HIV-1 vaccines expand the breadth and depth of cellular immune responses in rhesus monkeys. Nat Med. 2010;16(3):319-323.

38. Parren PW, Marx PA, Hessell AJ, et al. Antibody protects macaques against vaginal challenge with a pathogenic R5 simian/human immunodeficiency virus at serum levels giving complete neutralization in vitro. J Virol. 2001;75(17):8340-8347.

39. Baba TW, Liska V, Hofmann-Lehmann R, et al. Human neutralizing monoclonal antibodies of the IgG1 subtype protect against mucosal simian-human immunodeficiency virus infection. Nat Med. 2000;6(2):200-206.

40. Mascola JR, Stiegler G, VanCott TC, et al. Protection of macaques against vaginal transmission of a pathogenic HIV-1/SIV chimeric virus by passive infusion of neutralizing antibodies. Nat Med. 2000;6(2):207-210.

41. Korber B, Gaschen B, Yusim K, Thakallapally R, Kesmir C, Detours V. Evolutionary and immunological implications of contemporary HIV-1 variation. Br Med Bull. 2001;58:19-42.

42. Wyatt R, Kwong PD, Desjardins E, et al. The antigenic structure of the HIV gp120 envelope glycoprotein. Nature. 1998;393(6686): 705-711.

43. Kwong PD, Wyatt R, Robinson J, Sweet RW, Sodroski J, Hendrickson WA. Structure of an HIV gp120 envelope glycoprotein in complex with the CD4 receptor and a neutralizing human antibody. Nature. 1998;393(6686):648-659.

44. Wei X, Decker JM, Wang S, et al. Antibody neutralization and escape by HIV-1. Nature. 2003;422(6929):307-312.

45. Fenouillet E, Barbouche R, Jones IM. Cell entry by enveloped viruses: redox considerations for HIV and SARS-coronavirus. Antioxid Redox Signal. 2007;9(8):1009-1034.

46. DeVico A, Fouts T, Lewis GK, et al. Antibodies to CD4-induced sites in HIV gp120 correlate with the control of SHIV challenge in macaques vaccinated with subunit immunogens. Proc Natl Acad Sci US A. 2007;104(44):17477-17482.

47. Walker LM, Phogat SK, Chan-Hui PY, et al. Broad and potent neutralizing antibodies from an African donor reveal a new HIV-1 vaccine target. Science. 2009;326(5950):285-289.

48. Burton DR, Pyati J, Koduri R, et al. Efficient neutralization of primary isolates of HIV-1 by a recombinant human monoclonal antibody. Science. 1994;266(5187):1024-1027.

49. Muster T, Steindl F, Purtscher M, et al. A conserved neutralizing epitope on gp41 of human immunodeficiency virus type 1. J Virol. 1993;67(11):6642-6647.

50. Stiegler G, Kunert R, Purtscher M, et al. A potent cross-clade neutralizing human monoclonal antibody against a novel epitope on gp41 of human immunodeficiency virus type 1. AIDS Res Hum Retroviruses. 2001;17(18):1757-1765.

51. Trkola A, Pomales AB, Yuan H, et al. Cross-clade neutralization of primary isolates of human immunodeficiency virus type 1 by human monoclonal antibodies and tetrameric CD4-IgG. J Virol. 1995;69(11):6609-6617. 
52. Lagenaur LA, Villarroel VA, Bundoc V, Dey B, Berger EA. sCD4-17b bifunctional protein: extremely broad and potent neutralization of HIV-1 Env pseudotyped viruses from genetically diverse primary isolates. Retrovirology. 2010;7:11.

53. Corti D, Langedijk JP, Hinz A, et al. Analysis of memory B cell responses and isolation of novel monoclonal antibodies with neutralizing breadth from HIV-1-infected individuals. PLoS One. 2010;5(1): e8805.

54. Easterbrook PJ, Schrager LK. Long-term nonprogression in HIV infection: methodological issues and scientific priorities. Report of an International European Community-National Institutes of Health Workshop, The Royal Society, London, England, 1995 Nov 27-29. Scientific Coordinating Committee. AIDS Res Hum Retroviruses. 1998; 14(14):1211-1228.

55. Paroli M, Propato A, Accapezzato D, Francavilla V, Schiaffella E, Barnaba V. The immunology of HIV-infected long-term nonprogressors-a current view. Immunol Lett. 2001;79(1-2):127-129.

56. Johnson BK, Stone GA, et al. Long-term observations of human immunodeficiency virus-infected chimpanzees. AIDS Res Hum Retroviruses. 1993;9(4):375-378.

57. Gardner MB. Simian and feline immunodeficiency viruses: animal lentivirus models for evaluation of AIDS vaccines and antiviral agents. Antiviral Res. 1991;15(4):267-286.

58. Podell M, March PA, Buck WR, Mathes LE. The feline model of neuroAIDS: understanding the progression towards AIDS dementia. J Psychopharmacol. 2000;14(3):205-213.

59. Yamamoto JK, Sanou MP, Abbott JR, Coleman JK. Feline immunodeficiency virus model for designing HIV/AIDS vaccines. Curr HIV Res. 2010;8(1):14-25.

60. Mosier DE, Gulizia RJ, Baird SM, Wilson DB, Spector DH, Spector SA. Human immunodeficiency virus infection of human-PBL-SCID mice. Science. 1991;251(4995):791-794.

61. McCune JM, Namikawa R, Shih CC, Rabin L, Kaneshima H. Suppression of HIV infection in AZT-treated SCID-hu mice. Science. 1990; 247(4942):564-566.

62. Baenziger S, Tussiwand R, Schlaepfer E, et al. Disseminated and sustained HIV infection in CD34+ cord blood cell-transplanted Rag2-/-gamma c-/- mice. Proc Natl Acad Sci U S A. 2006;103(43): 15951-15956.

63. Gardner MB, Luciw PA. Animal models of AIDS. FASEB J. 1989;3(14): 2593-2606.

64. Li J, Lord CI, Haseltine W, Letvin NL, Sodroski J. Infection of cynomolgus monkeys with a chimeric HIV-1/SIVmac virus that expresses the HIV-1 envelope glycoproteins. J Acquir Immune Defic Syndr. 1992; 5(7):639-646.

65. Reimann KA, Li JT, Veazey R, et al. A chimeric simian/human immunodeficiency virus expressing a primary patient human immunodeficiency virus type 1 isolate env causes an AIDS-like disease after in vivo passage in rhesus monkeys. J Virol. 1996;70(10):6922-6928.

66. Nishimura Y, Igarashi T, Donau OK, et al. Highly pathogenic SHIVs and SIVs target different CD4+ T cell subsets in rhesus monkeys, explaining their divergent clinical courses. Proc Natl Acad Sci U S A. 2004;101(33):12324-12329.

67. Buchbinder SP, Mehrotra DV, Duerr A, et al. Efficacy assessment of a cell-mediated immunity HIV-1 vaccine (the Step Study): a doubleblind, randomised, placebo-controlled, test-of-concept trial. Lancet. 2008;372(9653):1881-1893.

68. Shiver JW, Fu TM, Chen L, et al. Replication-incompetent adenoviral vaccine vector elicits effective anti-immunodeficiency-virus immunity. Nature. 2002;415(6869):331-335.

69. Kestler HW III, Ringler DJ, Mori K, et al. Importance of the nef gene for maintenance of high virus loads and for development of AIDS. Cell. 1991;65(4):651-662.

70. Daniel MD, Kirchhoff F, Czajak SC, Sehgal PK, Desrosiers RC. Protective effects of a live attenuated SIV vaccine with a deletion in the nef gene. Science. 1992;258(5090): 1938-1941.
71. Rud EW, Cranage M, Yon J, et al. Molecular and biological characterization of simian immunodeficiency virus macaque strain $32 \mathrm{H}$ proviral clones containing nef size variants. J Gen Virol. 1994;75(Pt 3):529-543.

72. Cranage MP, Whatmore AM, Sharpe SA, et al. Macaques infected with live attenuated SIVmac are protected against superinfection via the rectal mucosa. Virology. 1997;229(1):143-154.

73. Marthas ML, Sutjipto S, Higgins J, et al. Immunization with a live, attenuated simian immunodeficiency virus (SIV) prevents early disease but not infection in rhesus macaques challenged with pathogenic SIV. J Virol. 1990;64(8):3694-3700.

74. Shacklett BL, Shaw KE, Adamson LA, et al. Live, attenuated simian immunodeficiency virus SIVmac-M4, with point mutations in the Env transmembrane protein intracytoplasmic domain, provides partial protection from mucosal challenge with pathogenic SIVmac251. J Virol. 2002;76(22):11365-11378.

75. Protection of macaques against simian immunodeficiency virus infection with inactivated vaccines: comparison of adjuvants, doses and challenge viruses. The European Concerted Action on 'Macaque Models for AIDS Research'. Vaccine. 1995;13(3):295-300.

76. Putkonen P, Nilsson C, Hild K, et al. Whole inactivated SIV vaccine grown on human cells fails to protect against homologous SIV grown on simian cells. J Med Primatol. 1993;22(2-3):100-103.

77. Stahl-Hennig C, Voss G, Dittmer U, et al. Protection of monkeys by a split vaccine against SIVmac depends upon biological properties of the challenge virus. AIDS. 1993;7(6):787-795.

78. Kusuhara H, Hohdatsu T, Okumura M, et al. Dual-subtype vaccine (FelO-Vax FIV) protects cats against contact challenge with heterologous subtype B FIV infected cats. Vet Microbiol. 2005;108(3-4):155-165.

79. Pu R, Coleman J, Omori M, et al. Dual-subtype FIV vaccine protects cats against in vivo swarms of both homologous and heterologous subtype FIV isolates. AIDS. 2001;15(10):1225-1237.

80. Hohdatsu T, Okada S, Motokawa K, Aizawa C, Yamamoto JK, Koyama $\mathrm{H}$. Effect of dual-subtype vaccine against feline immunodeficiency virus infection. Vet Microbiol. 1997;58(2-4):155-165.

81. Pu R, Coleman J, Coisman J, et al. Dual-subtype FIV vaccine (FelO-Vax FIV) protection against a heterologous subtype B FIV isolate. J Feline Med Surg. 2005;7(1):65-70.

82. Birx DL, Loomis-Price LD, Aronson N, et al. Efficacy testing of recombinant human immunodeficiency virus (HIV) gp160 as a therapeutic vaccine in early-stage HIV-1-infected volunteers. rgp160 hase II Vaccine Investigators. J Infect Dis. 2000;181(3):881-889.

83. Eron JJ Jr, Ashby MA, Giordano MF, et al. Randomised trial of MNrgp120 HIV-1 vaccine in symptomless HIV-1 infection. Lancet. 1996;348(9041):1547-1551.

84. Pontesilli O, Guerra EC, Ammassari A, et al. Phase II controlled trial of post-exposure immunization with recombinant gp160 versus antiretroviral therapy in asymptomatic HIV-1-infected adults. VaxSyn Protocol Team. AIDS. 1998;12(5):473-480.

85. Ratto-Kim S, Sitz KV, Garner RP, et al. Repeated immunization with recombinant gp160 human immunodeficiency virus (HIV) envelope protein in early HIV-1 infection: evaluation of the T cell proliferative response. J Infect Dis. 1999;179(2):337-344.

86. Redfield RR, Birx DL, Ketter N, et al. A phase I evaluation of the safety and immunogenicity of vaccination with recombinant gp 160 in patients with early human immunodeficiency virus infection. Military Medical Consortium for Applied Retroviral Research. $N$ Engl J Med. 1991;324(24):1677-1684.

87. Schooley RT, Spino C, Kuritzkes D, et al. Two double-blinded, randomized, comparative trials of 4 human immunodeficiency virus type 1 (HIV-1) envelope vaccines in HIV-1-infected individuals across a spectrum of disease severity: AIDS Clinical Trials Groups 209 a nd 214. J Infect Dis. 2000;182(5):1357-1364.

88. Valentine FT, Kundu S, Haslett PA, et al. A randomized, placebocontrolled study of the immunogenicity of human immunodeficiency virus (HIV) rgp160 vaccine in HIV-infected subjects with $>$ or $=400$ / mm3 CD4 T lymphocytes (AIDS Clinical Trials Group Protocol 137). J Infect Dis. 1996;173(6):1336-1346. 
89. Wahren B, Bratt G, Persson C, et al. Improved cell-mediated immune responses in HIV-1-infected asymptomatic individuals after immunization with envelope glycoprotein gp160. JAcquir Immune Defic Syndr. 1994;7(3):220-229.

90. Wright PF, Lambert JS, Gorse GJ, et al. Immunization with envelope MN rgp120 vaccine in human immunodeficiency virus-infected pregnant women. J Infect Dis. 1999;180(4):1080-1088.

91. Weber J, Cheinsong-Popov R, Callow D, et al. Immunogenicity of the yeast recombinant p17/p24:Ty virus-like particles (p24-VLP) in healthy volunteers. Vaccine. 1995;13(9):831-834.

92. Veenstra J, Williams IG, Colebunders R, et al. Immunization with recombinant $\mathrm{p} 17 / \mathrm{p} 24$ :Ty virus-like particles in human immunodeficiency virus-infected persons. J Infect Dis. 1996;174(4):862-866.

93. Kelleher AD, Roggensack M, Jaramillo AB, et al. Safety and immunogenicity of a candidate therapeutic vaccine, $\mathrm{p} 24$ virus-like particle, combined with zidovudine, in asymptomatic subjects. Community HIV Research Network Investigators. AIDS. 1998;12(2):175-182.

94. Benson EM, Clarkson J, Law M, et al. Therapeutic vaccination with p24-VLP and zidovudine augments HIV-specific cytotoxic T lymphocyte activity in asymptomatic HIV-infected individuals. AIDS Res Hum Retroviruses. 1999;15(2):105-113.

95. Okuda K, Bukawa H, Hamajima K, et al. Induction of potent humoral and cell-mediated immune responses following direct injection of DNA encoding the HIV type 1 env and rev gene products. AIDS Res Hum Retroviruses. 1995;11(8):933-943.

96. Neumann J, Stitz J, Konig R, et al. Retroviral vectors for vaccine development: induction of HIV-1-specific humoral and cellular immune responses in rhesus macaques using a novel MLV(HIV-1) pseudotype vector. J Biotechnol. 2006;124(3):615-625.

97. Buffa V, Negri DR, Leone P, et al. A single administration of lentiviral vectors expressing either full-length human immunodeficiency virus 1 (HIV-1)(HXB2) Rev/Env or codon-optimized HIV-1(JR-FL) gp120 generates durable immune responses in mice. J Gen Virol. 2006;87(Pt 6):1625-1634.

98. Faul EJ, Aye PP, Papaneri AB, et al. Rabies virus-based vaccines elicit neutralizing antibodies, poly-functional $\mathrm{CD} 8+\mathrm{T}$ cell, and protect rhesus macaques from AIDS-like disease after SIV(mac251) challenge. Vaccine. 2009;28(2):299-308.

99. McKenna PM, Koser ML, Carlson KR, et al. Highly attenuated rabies virus-based vaccine vectors expressing simian-human immunodeficiency virus89.6P Env and simian immunodeficiency virusmac239 Gag are safe in rhesus macaques and protect from an AIDS-like disease. J Infect Dis. 2007;195(7):980-988.

100. Quinnan GV Jr, Yu XF, Lewis MG, et al. Protection of rhesus monkeys against infection with minimally pathogenic simian-human immunodeficiency virus: correlations with neutralizing antibodies and cytotoxic T cells. J Virol. 2005;79(6):3358-3369.

101. Rerks-Ngarm S, Pitisuttithum P, Nitayaphan S, et al. Vaccination with ALVAC and AIDSVAX to prevent HIV-1 infection in Thailand. N Engl J Med. 2009;361(23):2209-2220.

102. Johnson PR, Schnepp BC, Zhang J, et al. Vector-mediated gene transfer engenders long-lived neutralizing activity and protection against SIV infection in monkeys. Nat Med. 2009;15(8):901-906.

103. Chenciner N, Randrianarison-Jewtoukoff V, Delpeyroux F, et al. Enhancement of humoral immunity to SIVenv following simultaneous inoculation of mice by three recombinant adenoviruses encoding SIVenv/poliovirus chimeras, Tat and Rev. AIDS Res Hum Retroviruses. 1997;13(9):801-806.

104. Santra S, Seaman MS, Xu L, et al. Replication-defective adenovirus serotype 5 vectors elicit durable cellular and humoral immune responses in nonhuman primates. J Virol. 2005;79(10):6516-6522.

105. Natuk RJ, Davis AR, Chanda PK, et al. Adenovirus vectored vaccines. Dev Biol Stand. 1994;82:71-77.

106. Bruce CB, Akrigg A, Sharpe SA, Hanke T, Wilkinson GW, Cranage MP. Replication-deficient recombinant adenoviruses expressing the human immunodeficiency virus Env antigen can induce both humoral and CTL immune responses in mice. J Gen Virol. 1999; 80(Pt 10): 2621-2628.
107. Zhan X, Martin LN, Slobod KS, et al. Multi-envelope HIV-1 vaccine devoid of SIV components controls disease in macaques challenged with heterologous pathogenic SHIV. Vaccine. 2005;23(46-47): 5306-5320.

108. Laube LS, Burrascano M, Dejesus CE, et al. Cytotoxic T lymphocyte and antibody responses generated in rhesus monkeys immunized with retroviral vector-transduced fibroblasts expressing human immunodeficiency virus type-1 IIIB ENV/REV proteins. Hum Gene Ther. 1994;5(7):853-862.

109. Buffa V, Negri DR, Leone P, et al. Evaluation of a self-inactivating lentiviral vector expressing simian immunodeficiency virus gag for induction of specific immune responses in vitro and in vivo. Viral Immunol. 2006;19(4):690-701.

110. Halsey RJ, Tanzer FL, Meyers A, et al. Chimaeric HIV-1 subtype C Gag molecules with large in-frame C-terminal polypeptide fusions form virus-like particles. Virus Res. 2008;133(2):259-268.

111. Pillay S, Meyers A, Williamson AL, Rybicki EP. Optimization of chimeric HIV-1 virus-like particle production in a baculovirus-insect cell expression system. Biotechnol Prog. 2009;25(4):1153-1160.

112. Deml L, Kratochwil G, Osterrieder N, Knuchel R, Wolf H, Wagner R. Increased incorporation of chimeric human immunodeficiency virus type 1 gp120 proteins into Pr55 gag virus-like particles by an Epstein-Barr virus gp220/350-derived transmembrane domain. Virology. 1997;235(1):10-25.

113. Deml L, Schirmbeck R, Reimann J, Wolf H, Wagner R. Recombinant human immunodeficiency Pr55 gag virus-like particles presenting chimeric envelope glycoproteins induce cytotoxic T-cells and neutralizing antibodies. Virology. 1997;235(1):26-39.

114. Kang CY, Luo L, Wainberg MA, Li Y. Development of HIV/AIDS vaccine using chimeric gag-env virus-like particles. Biol Chem. 1999; 380(3):353-364.

115. Donnelly JJ, Ulmer JB, Shiver JW, Liu MA. DNA vaccines. Annu Rev Immunol. 1997;15:617-648.

116. Garzon MR, Berraondo P, Crettaz J, et al. Induction of gp120-specific protective immune responses by genetic vaccination with linear polyethylenimine-plasmid complex. Vaccine. 2005;23(11):1384-1392.

117. Liu MA. DNA vaccines: a review. J Intern Med. 2003;253(4): 402-410.

118. Raska M, Belakova J, Wudattu NK, et al. Comparison of protective effect of protein and DNA vaccines hsp90 in murine model of systemic candidiasis. Folia Microbiol (Praha). 2005;50(1):77-82.

119. Giri M, Ugen KE, Weiner DB. DNA vaccines against human immunodeficiency virus type 1 in the past decade. Clin Microbiol Rev. 2004;17(2):370-389.

120. Wolff JA, Malone RW, Williams P, et al. Direct gene transfer into mouse muscle in vivo. Science. 1990;247(4949 Pt 1):1465-1468.

121. Calarota SA, Weiner DB. Enhancement of human immunodeficiency virus type 1-DNA vaccine potency through incorporation of T-helper 1 molecular adjuvants. Immunol Rev. 2004;199:84-99.

122. Billaut-Mulot O, Idziorek T, Loyens M, Capron A, Bahr GM. Modulation of cellular and humoral immune responses to a multiepitopic HIV-1 DNA vaccine by interleukin-18 DNA immunization/ viral protein boost. Vaccine. 2001;19(20-22):2803-2811.

123. Dale CJ, de Rose R, Wilson KM, et al. Evaluation in macaques of HIV-1 DNA vaccines containing primate $\mathrm{CpG}$ motifs and fowlpoxvirus vaccines co-expressing IFNgamma or IL-12. Vaccine. 2004;23(2): 188-197.

124. Barouch DH, Santra S, Steenbeke TD, et al. Augmentation and suppression of immune responses to an HIV-1 DNA vaccine by plasmid cytokine/Ig administration. J Immunol. 1998;161(4):1875-1882.

125. Hashida M, Nishikawa M, Yamashita F, Takakura Y. Cell-specific delivery of genes with glycosylated carriers. Adv Drug Deliv Rev. 2001;52(3):187-196.

126. Zhang Y, Schlachetzki F, Li JY, Boado RJ, Pardridge WM. Organspecific gene expression in the rhesus monkey eye following intravenous non-viral gene transfer. Mol Vis. 2003;9:465-472.

127. Zou SM, Erbacher P, Remy JS, Behr JP. Systemic linear polyethylenimine (L-PEI)-mediated gene delivery in the mouse. J Gene Med. 2000;2(2):128-134. 
128. Zuber G, Zammut-Italiano L, Dauty E, Behr JP. Targeted gene delivery to cancer cells: directed assembly of nanometric DNA particles coated with folic acid. Angew Chem Int Ed Engl. 2003;42(23): 2666-2669

129. Harari A, Bart PA, Stohr W, et al. An HIV-1 clade C DNA prime, NYVAC boost vaccine regimen induces reliable, polyfunctional, and long-lasting T cell responses. J Exp Med. 2008;205(1):63-77.

130. Jaoko W, Karita E, Kayitenkore K, et al. Safety and immunogenicity study of multiclade HIV-1 adenoviral vector vaccine alone or as boost following a multiclade HIV-1 DNA vaccine in Africa. PLoS One. 2010;5(9):e12873.

131. Combe E, Pirman T, Stekar J, Houlier ML, Mirand PP. Differential effect of lentil feeding on proteosynthesis rates in the large intestine, liver and muscle of rats. J Nutr Biochem. 2004;15(1):12-17.

132. Raska M, Moldoveanu Z, Novak J, et al. Delivery of DNA HIV-1 vaccine to the liver induces high and long-lasting humoral immune responses. Vaccine. 2008;26(12):1541-1551.

133. Letvin NL, Walker BD. Immunopathogenesis and immunotherapy in AIDS virus infections. Nat Med. 2003;9(7):861-866.

134. Reitter JN, Means RE, Desrosiers RC. A role for carbohydrates in immune evasion in AIDS. Nat Med. 1998;4(6):679-684.

135. Heller L, Jaroszeski MJ, Coppola D, Pottinger C, Gilbert R, Heller R. Electrically mediated plasmid DNA delivery to hepatocellular carcinomas in vivo. Gene Ther. 2000;7(10):826-829.

136. Vorup-Jensen T, Jensen UB, Liu H, et al. Tail-vein injection of mannan-binding lectin DNA leads to high expression levels of multimeric protein in liver. Mol Ther. 2001;3(6):867-874.

137. BudkerVG, Subbotin VM, Budker T, Sebestyen MG, Zhang G, Wolff JA Mechanism of plasmid delivery by hydrodynamic tail vein injection II. Morphological studies. J Gene Med. 2006;8(7):874-888.

138. Sebestyen MG, Budker VG, Budker T, et al. Mechanism of plasmid delivery by hydrodynamic tail vein injection. I. Hepatocyte uptake of various molecules. J Gene Med. 2006;8(7):852-873.

139. Budker V, Zhang G, Danko I, Williams P, Wolff J. The efficient expression of intravascularly delivered DNA in rat muscle. Gene Ther. 1998;5(2):272-276.

140. Liu F, Song Y, Liu D. Hydrodynamics-based transfection in animals by systemic administration of plasmid DNA. Gene Ther. 1999;6(7):1258-1266.

141. Zhang G, Budker V, Wolff JA. High levels of foreign gene expression in hepatocytes after tail vein injections of naked plasmid DNA. Hum Gene Ther. 1999;10(10):1735-1737.

142. Suda T, Liu D. Hydrodynamic gene delivery: its principles and applications. Mol Ther. 2007;15(12):2063-2069.

143. Stockert RJ. The asialoglycoprotein receptor: relationships between structure, function, and expression. Physiol Rev. 1995;75(3): 591-609.

144. Maier MA, Yannopoulos CG, Mohamed N, et al. Synthesis of antisense oligonucleotides conjugated to a multivalent carbohydrate cluster for cellular targeting. Bioconjug Chem. 2003;14(1):18-29.

145. Waddington SN, McVey JH, Bhella D, et al. Adenovirus serotype 5 hexon mediates liver gene transfer. Cell. 2008;132(3): 397-409.

146. Kalyuzhniy O, di Paolo NC, Silvestry M, et al. Adenovirus serotype 5 hexon is critical for virus infection of hepatocytes in vivo. Proc Natl Acad Sci U S A. 2008;105(14):5483-5488.

147. Li S, Locke E, Bruder J, et al. Viral vectors for malaria vaccine development. Vaccine. 2007;25(14):2567-2574.

148. Smith AD, Geisler SC, Chen AA, et al. Human rhinovirus type 14:human immunodeficiency virus type 1 (HIV-1) V3 loop chimeras from a combinatorial library induce potent neutralizing antibody responses against HIV-1. J Virol. 1998;72(1):651-659.

149. Arnold GF, Velasco PK, Holmes AK, et al. Broad neutralization of human immunodeficiency virus type 1 (HIV-1) elicited from human rhinoviruses that display the HIV-1 gp41 ELDKWA epitope. J Virol. 2009;83(10):5087-5100.

150. Patterson S, Papagatsias T, Benlahrech A. Use of adenovirus in vaccines for HIV. Handb Exp Pharmacol. 2009;(188):275-293.
151. Bangari DS, Mittal SK. Development of nonhuman adenoviruses as vaccine vectors. Vaccine. 2006;24(7):849-862.

152. Crotty S, Andino R. Poliovirus vaccine strains as mucosal vaccine vectors and their potential use to develop an AIDS vaccine. Adv Drug Deliv Rev. 2004;56(6):835-852.

153. Amara RR, Villinger F, Altman JD, et al. Control of a mucosal challenge and prevention of AIDS by a multiprotein DNA/MVA vaccine. Science. 2001;292(5514):69-74.

154. Gherardi MM, Esteban M. Recombinant poxviruses as mucosal vaccine vectors. J Gen Virol. 2005;86(Pt 11):2925-2936.

155. Langley WA, Bradley KC, Li ZN, Smith ME, Schnell MJ, Steinhauer DA. Induction of neutralizing antibody responses to anthrax protective antigen by using influenza virus vectors: implications for disparate immune system priming pathways. J Virol. 2010;84(16): 8300-8307.

156. Slobod KS, Lockey TD, Howlett N, et al. Subcutaneous administration of a recombinant vaccinia virus vaccine expressing multiple envelopes of HIV-1. Eur J Clin Microbiol Infect Dis. 2004;23(2):106-110.

157. Dmitriev I, Krasnykh V, Miller CR, et al. An adenovirus vector with genetically modified fibers demonstrates expanded tropism via utilization of a coxsackievirus and adenovirus receptor-independent cell entry mechanism. J Virol. 1998;72(12):9706-9713.

158. Barnett BG, Crews CJ, Douglas JT. Targeted adenoviral vectors. Biochim Biophys Acta. 2002;1575(1-3):1-14.

159. Kay MA, Glorioso JC, Naldini L. Viral vectors for gene therapy: the art of turning infectious agents into vehicles of therapeutics. Nat Med. 2001;7(1):33-40

160. Tangy F, Naim HY. Live attenuated measles vaccine as a potential multivalent pediatric vaccination vector. Viral Immunol. 2005;18(2): 317-326.

161. Esolen LM, Ward BJ, Moench TR, Griffin DE. Infection of monocytes during measles. J Infect Dis. 1993;168(1):47-52.

162. Hilleman MR. Vaccinology, immunology, and comparative pathogenesis of measles in the quest for a preventative against AIDS. AIDS Res Hum Retroviruses. 1994;10(1):3-12.

163. Mandl S, Hix L, Andino R. Preexisting immunity to poliovirus does not impair the efficacy of recombinant poliovirus vaccine vectors. J Virol. 2001;75(2):622-627.

164. Thacker E, Timares L, Matthews QL. Strategies to overcome host immunity to adenovirus vectors in vaccine development. Expert Rev Vaccines. 2009;8(6):761-777.

165. Sumida SM, Truitt DM, Lemckert AA, et al. Neutralizing antibodies to adenovirus serotype 5 vaccine vectors are directed primarily against the adenovirus hexon protein. J Immunol. 2005;174(11):7179-7185.

166. Wu H, Dmitriev I, Kashentseva E, Seki T, Wang M, Curiel DT. Construction and characterization of adenovirus serotype 5 packaged by serotype 3 hexon. J Virol. 2002;76(24):12775-12782.

167. Roberts DM, Nanda A, Havenga MJ, et al. Hexon-chimaeric adenovirus serotype 5 vectors circumvent pre-existing anti-vector immunity Nature. 2006;441(7090):239-243.

168. Chirmule N, Propert K, Magosin S, Qian Y, Qian R, Wilson J. Immune responses to adenovirus and adeno-associated virus in humans. Gene Ther. 1999;6(9):1574-1583.

169. Kass-Eisler A, Falck-Pedersen E, Elfenbein DH, Alvira M, Buttrick PM, Leinwand LA. The impact of developmental stage, route of administration and the immune system on adenovirus-mediated gene transfer. Gene Ther. 1994;1(6):395-402.

170. Kass-Eisler A, Leinwand L, Gall J, Bloom B, Falck-Pedersen E. Circumventing the immune response to adenovirus-mediated gene therapy. Gene Ther. 1996;3(2):154-162.

171. Youil R, Toner TJ, Su Q, et al. Hexon gene switch strategy for the generation of chimeric recombinant adenovirus. Hum Gene Ther 2002;13(2):311-320.

172. Mastrangeli A, Harvey BG, Yao J, et al. 'Sero-switch' adenovirusmediated in vivo gene transfer: circumvention of anti-adenovirus humoral immune defenses against repeat adenovirus vector administration by changing the adenovirus serotype. Hum Gene Ther. 1996;7(1):79-87. 
173. Moffatt S, Hays J, HogenEsch H, Mittal SK. Circumvention of vectorspecific neutralizing antibody response by alternating use of human and non-human adenoviruses: implications in gene therapy. Virology. 2000;272(1):159-167.

174. Lemckert AA, Grimbergen J, Smits S, et al. Generation of a novel replication-incompetent adenoviral vector derived from human adenovirus type 49: manufacture on PER.C6 cells, tropism and immunogenicity. J Gen Virol. 2006;87(Pt 10):2891-2899.

175. Shayakhmetov DM, Lieber A. Dependence of adenovirus infectivity on length of the fiber shaft domain. J Virol. 2000;74(22):10274-10286.

176. Kidd AH, Chroboczek J, Cusack S, Ruigrok RW. Adenovirus type 40 virions contain two distinct fibers. Virology. 1993;192(1):73-84.

177. Yeh HY, Pieniazek N, Pieniazek D, Gelderblom H, Luftig RB. Human adenovirus type 41 contains two fibers. Virus Res. 1994;33(2): 179-198.

178. Pichla-Gollon SL, Drinker M, Zhou X, et al. Structure-based identification of a major neutralizing site in an adenovirus hexon. $J$ Virol. 2007;81(4):1680-1689.

179. Roy S, Gao G, Lu Y, et al. Characterization of a family of chimpanzee adenoviruses and development of molecular clones for gene transfer vectors. Hum Gene Ther. 2004;15(5):519-530.

180. Farina SF, Gao GP, Xiang ZQ, et al. Replication-defective vector based on a chimpanzee adenovirus. J Virol. 2001;75(23): 11603-11613.

181. Kobinger GP, Feldmann H, Zhi Y, et al. Chimpanzee adenovirus vaccine protects against Zaire Ebola virus. Virology. 2006;346(2): 394-401.

182. Umana P, Gerdes CA, Stone D, et al. Efficient FLPe recombinase enables scalable production of helper-dependent adenoviral vectors with negligible helper-virus contamination. Nat Biotechnol. 2001;19(6):582-585.

183. Lowenstein PR, Thomas CE, Umana P, et al. High-capacity, helperdependent, 'gutless' adenoviral vectors for gene transfer into brain. Methods Enzymol. 2002;346:292-311.

184. Xiong W, Goverdhana S, Sciascia SA, et al. Regulatable gutless adenovirus vectors sustain inducible transgene expression in the brain in the presence of an immune response against adenoviruses. J Virol. 2006;80(1):27-37.

185. Xiong W, Candolfi M, Kroeger KM, et al. Immunization against the transgene but not the TetON switch reduces expression from gutless adenoviral vectors in the brain. Mol Ther. 2008;16(2):343-351.

186. Weaver EA, Nehete PN, Buchl SS, et al. Comparison of replicationcompetent, first generation, and helper-dependent adenoviral vaccines. PLoS One. 2009;4(3):e5059.

187. Weaver EA, Nehete PN, Nehete BP, et al. Protection against mucosal SHIV challenge by peptide and helper-dependent adenovirus vaccines. Viruses. 2009;1(3):920-938.

188. Weaver EA, Barry MA. Effects of shielding adenoviral vectors with polyethylene glycol (PEG) on vector-specific and vaccine-mediated immune responses. Hum Gene Ther. 2008;19(12):1369-1382.

189. O’Riordan CR, Song A. PEGylated adenovirus for targeted gene therapy. Methods Mol Biol. 2008;434:133-160.

190. Eto Y, Yoshioka Y, Mukai Y, Okada N, Nakagawa S. Development of PEGylated adenovirus vector with targeting ligand. Int J Pharm. 2008;354(1-2):3-8.

191. Eto Y, Gao JQ, Sekiguchi F, et al. Neutralizing antibody evasion ability of adenovirus vector induced by the bioconjugation of methoxypolyethylene glycol succinimidyl propionate (MPEG-SPA). Biol Pharm Bull. 2004;27(6):936-938.

192. Eto Y, Gao JQ, Sekiguchi F, et al. PEGylated adenovirus vectors containing RGD peptides on the tip of PEG show high transduction efficiency and antibody evasion ability. J Gene Med. 2005; 7(5):604-612.

193. Mok H, Palmer DJ, Ng P, Barry MA. Evaluation of polyethylene glycol modification of first-generation and helper-dependent adenoviral vectors to reduce innate immune responses. Mol Ther. 2005;11(1):66-79.
194. Croyle MA, Le HT, Linse KD, et al. PEGylated helper-dependent adenoviral vectors: highly efficient vectors with an enhanced safety profile. Gene Ther. 2005;12(7):579-587.

195. Zabaleta A, Llopiz D, Arribillaga L, et al. Vaccination against hepatitis $\mathrm{C}$ virus with dendritic cells transduced with an adenovirus encoding NS3 protein. Mol Ther. 2008;16(1):210-217.

196. Roth JC, Curiel DT, Pereboeva L. Cell vehicle targeting strategies. Gene Ther. 2008;15(10):716-729.

197. Bangari DS, Mittal SK. Current strategies and future directions for eluding adenoviral vector immunity. Curr Gene Ther. 2006;6(2):215-226.

198. Brown BD, Shi CX, Rawle FE, et al. Factors influencing therapeutic efficacy and the host immune response to helper-dependent adenoviral gene therapy in hemophilia A mice. J Thromb Haemost. 2004;2(1):111-118.

199. de Geest B, Snoeys J, van Linthout S, Lievens J, Collen D. Elimination of innate immune responses and liver inflammation by PEGylation of adenoviral vectors and methylprednisolone. Hum Gene Ther. 2005;16(12):1439-1451.

200. Morral N, O'Neal W, Rice K, et al. Administration of helper-dependent adenoviral vectors and sequential delivery of different vector serotype for long-term liver-directed gene transfer in baboons. Proc Natl Acad Sci U S A. 1999;96(22):12816-12821.

201. Hutnick NA, Carnathan DG, Dubey SA, et al. Baseline Ad5 serostatus does not predict Ad5 HIV vaccine-induced expansion of adenovirusspecific CD4+ T cells. Nat Med. 2009;15(8):876-878.

202. Kaufman DR, Barouch DH. Translational mini-review series on vaccines for HIV: T lymphocyte trafficking and vaccine-elicited mucosal immunity. Clin Exp Immunol. 2009;157(2):165-173.

203. Kaufman DR, Bivas-Benita M, Simmons NL, Miller D, Barouch DH. Route of adenovirus-based HIV-1 vaccine delivery impacts the phenotype and trafficking of vaccine-elicited CD8+ T lymphocytes. J Virol. 2010;84(12):5986-5996.

204. Cheng C, Gall JG, Nason M, et al. Differential specificity and immunogenicity of adenovirus type 5 neutralizing antibodies elicited by natural infection or immunization. J Virol. 2010;84(1):630-638.

205. Ogra PL, Karzon DT. Distribution of poliovirus antibody in serum, nasopharynx and alimentary tract following segmental immunization of lower alimentary tract with poliovaccine. J Immunol. 1969; 102(6):1423-1430.

206. Ogra PL, Ogra SS, al-Nakeeb S, Coppola PR. Local antibody response to experimental poliovirus infection in the central nervous system of rhesus monkeys. Infect Immun. 1973;8(6):931-937.

207. Ahlers JD, Belyakov IM. Strategies for optimizing targeting and delivery of mucosal HIV vaccines. Eur J Immunol. 2009;39(10):2657-2669.

208. Mehandru S, Poles MA, Tenner-Racz K, et al. Primary HIV-1 infection is associated with preferential depletion of CD4+ T lymphocytes from effector sites in the gastrointestinal tract. J Exp Med. 2004; 200(6):761-770.

209. Brenchley JM, Schacker TW, Ruff LE, et al. CD4+ T cell depletion during all stages of HIV disease occurs predominantly in the gastrointestinal tract. J Exp Med. 2004;200(6):749-759.

210. Belyakov IM, Hel Z, Kelsall B, et al. Mucosal AIDS vaccine reduces disease and viral load in gut reservoir and blood after mucosal infection of macaques. Nat Med. 2001;7(12):1320-1326.

211. Belyakov IM, Kuznetsov VA, Kelsall B, et al. Impact of vaccineinduced mucosal high-avidity CD8+ CTLs in delay of AIDS viral dissemination from mucosa. Blood. 2006;107(8):3258-3264.

212. Belyakov IM, Isakov D, Zhu Q, Dzutsev A, Berzofsky JA. A novel functional CTL avidity/activity compartmentalization to the site of mucosal immunization contributes to protection of macaques against simian/human immunodeficiency viral depletion of mucosal CD4+ T cells. J Immunol. 2007;178(11):7211-7221.

213. Staats HF, Montgomery SP, Palker TJ. Intranasal immunization is superior to vaginal, gastric, or rectal immunization for the induction of systemic and mucosal anti-HIV antibody responses. AIDS Res Hum Retroviruses. 1997;13(11): 945-952. 
214. Kozlowski PA, Cu-Uvin S, Neutra MR, Flanigan TP. Comparison of the oral, rectal, and vaginal immunization routes for induction of antibodies in rectal and genital tract secretions of women. Infect Immun. 1997;65(4):1387-1394.

215. Gorelick RJ, Benveniste RE, Gagliardi TD, et al. Nucleocapsid protein zinc-finger mutants of simian immunodeficiency virus strain mne produce virions that are replication defective in vitro and in vivo. Virology. 1999;253(2):259-270.

216. Sauter MM, Pelchen-Matthews A, Bron R, et al. An internalization signal in the simian immunodeficiency virus transmembrane protein cytoplasmic domain modulates expression of envelope glycoproteins on the cell surface. J Cell Biol. 1996;132(5): 795-811.

217. Hessell AJ, Rakasz EG, Tehrani DM, et al. Broadly neutralizing monoclonal antibodies 2F5 and 4E10 directed against the human immunodeficiency virus type 1 gp41 membrane-proximal external region protect against mucosal challenge by simian-human immunodeficiency virus SHIVBa-L. J Virol. 2010;84(3):1302-1313.

218. Natuk RJ, Lubeck MD, Chanda PK, et al. Immunogenicity of recombinant human adenovirus-human immunodeficiency virus vaccines in chimpanzees. AIDS Res Hum Retroviruses. 1993;9(5):395-404.

219. Lubeck MD, Natuk R, Myagkikh M, et al. Long-term protection of chimpanzees against high-dose HIV-1 challenge induced by immunization. Nat Med. 1997;3(6):651-658.

220. Patterson LJ, Malkevitch N, Venzon D, et al. Protection against mucosal simian immunodeficiency virus SIV(mac251) challenge by using replicating adenovirus-SIV multigene vaccine priming and subunit boosting. J Virol. 2004;78(5):2212-2221.

221. Malkevitch N, Rohne D, Pinczewski J, et al. Evaluation of combination DNA/replication-competent Ad-SIV recombinant immunization regimens in rhesus macaques. AIDS Res Hum Retroviruses. 2004;20(2):235-244.

222. Lemiale F, Haddada H, Nabel GJ, Brough DE, King CR, Gall JG. Novel adenovirus vaccine vectors based on the enteric-tropic serotype 41. Vaccine. 2007;25(11):2074-2084.

223. Christensen ML. Human viral gastroenteritis. Clin Microbiol Rev. 1989;2(1):51-89.

224. Favier AL, Burmeister WP, Chroboczek J. Unique physicochemical properties of human enteric Ad41 responsible for its survival and replication in the gastrointestinal tract. Virology. 2004;322(1): 93-104.

225. Pieniazek NJ, Slemenda SB, Pieniazek D, Velarde J Jr, Luftig RB. Human enteric adenovirus type 41 (Tak) contains a second fiber protein gene. Nucleic Acids Res. 1990;18(7):1901

226. McConnell MJ, Hanna PC, Imperiale MJ. Adenovirus-based primeboost immunization for rapid vaccination against anthrax. Mol Ther. 2007;15(1):203-210.

227. Sullivan NJ, Sanchez A, Rollin PE, Yang ZY, Nabel GJ. Development of a preventive vaccine for Ebola virus infection in primates. Nature. 2000;408(6812):605-609.

228. Liu RY, Wu LZ, Huang BJ, et al. Adenoviral expression of a truncated S1 subunit of SARS-CoV spike protein results in specific humoral immune responses against SARS-CoV in rats. Virus Res. 2005; 112(1-2):24-31.

229. Gomez-Roman VR, Robert-Guroff M. Adenoviruses as vectors for HIV vaccines. AIDS Rev. 2003;5(3):178-185.

230. McConnell MJ, Danthinne X, Imperiale MJ. Characterization of a permissive epitope insertion site in adenovirus hexon. $J$ Virol. 2006;80(11):5361-5370.

231. Schief WR, Ban YE, Stamatatos L. Challenges for structure-based HIV vaccine design. Curr Opin HIV AIDS. 2009;4(5):431-440.

232. Lin G, Nara PL. Designing immunogens to elicit broadly neutralizing antibodies to the HIV-1 envelope glycoprotein. Curr HIV Res. 2007;5(6):514-541.

233. Walker LM, Burton DR. Rational antibody-based HIV-1 vaccine design: current approaches and future directions. Curr Opin Immunol. 2010;22(3):358-366.
234. Liu J, Bartesaghi A, Borgnia MJ, Sapiro G, Subramaniam S Molecular architecture of native HIV-1 gp120 trimers. Nature. 2008;455(7209):109-113.

235. Zhou T, Xu L, Dey B, et al. Structural definition of a conserved neutralization epitope on HIV-1 gp120. Nature. 2007;445(7129):732-737.

236. Lifson JD, Martin MA. One step forwards, one step back. Nature. 2002;415(6869):272-273.

237. Letvin NL, Barouch DH, Montefiori DC. Prospects for vaccine protection against HIV-1 infection and AIDS. Annu Rev Immunol. 2002;20:73-99.

238. Worgall S, Busch A, Rivara M, et al. Modification to the capsid of the adenovirus vector that enhances dendritic cell infection and transgene-specific cellular immune responses. J Virol. 2004;78(5): 2572-2580.

239. Worgall S, Krause A, Rivara M, et al. Protection against P. aeruginosa with an adenovirus vector containing an OprF epitope in the capsid. $J$ Clin Invest. 2005;115(5):1281-1289.

240. Matthews QL, Yang P, Wu Q, et al. Optimization of capsid-incorporated antigens for a novel adenovirus vaccine approach. $J$ Virol. 2008;5:98.

241. Krause A, Joh JH, Hackett NR, et al. Epitopes expressed in different adenovirus capsid proteins induce different levels of epitope-specific immunity. J Virol. 2006;80(11):5523-5530.

242. Crompton J, Toogood CI, Wallis N, Hay RT. Expression of a foreign epitope on the surface of the adenovirus hexon. J Gen Virol. 1994; 75(Pt 1):133-139.

243. Wu H, Han T, Belousova N, et al. Identification of sites in adenovirus hexon for foreign peptide incorporation. J Virol. 2005;79(6): 3382-3390

244. Rux JJ, Kuser PR, Burnett RM. Structural and phylogenetic analysis of adenovirus hexons by use of high-resolution X-ray crystallographic, molecular modeling, and sequence-based methods. J Virol. 2003;77(17):9553-9566.

245. Worgall S, Krause A, Qiu J, Joh J, Hackett NR, Crystal RG. Protective immunity to pseudomonas aeruginosa induced with a capsid-modified adenovirus expressing P. aeruginosa OprF. J Virol. 2007;81(24):13801-13808.

246. Vigne E, Mahfouz I, Dedieu JF, Brie A, Perricaudet M, Yeh P. RGD inclusion in the hexon monomer provides adenovirus type 5-based vectors with a fiber knob-independent pathway for infection. J Virol. 1999;73(6):5156-5161

247. Abe S, Okuda K, Ura T, et al. Adenovirus type 5 with modified hexons induces robust transgene-specific immune responses in mice with pre-existing immunity against adenovirus type 5. J Gene Med. 2009;11(7):570-579.

248. Ofek G, Tang M, Sambor A, et al. Structure and mechanistic analysis of the anti-human immunodeficiency virus type 1 antibody 2F5 in complex with its gp41 epitope. J Virol. 2004;78(19): 10724-10737.

249. Matthews QL, Sibley DA, Wu H, et al. Genetic incorporation of a herpes simplex virus type 1 thymidine kinase and firefly luciferase fusion into the adenovirus protein IX for functional display on the virion. Mol Imaging. 2006;5(4):510-519.

250. Tang Y, Le LP, Matthews QL, Han T, Wu H, Curiel DT. Derivation of a triple mosaic adenovirus based on modification of the minor capsid protein IX. Virology. 2008;377(2):391-400.

251. Li J, Le L, Sibley DA, Mathis JM, Curiel DT. Genetic incorporation of HSV-1 thymidine kinase into the adenovirus protein IX for functional display on the virion. Virology. 2005;338(2):247-258.

252. Matthews QL, Fatima A, Tang Y, et al. HIV antigen incorporation within adenovirus hexon hypervariable 2 for a novel HIV vaccine approach. PLoS One. 2010;5(7):e11815.

253. Smith AD, Resnick DA, Zhang A, Geisler SC, Arnold E, Arnold GF. Use of random systematic mutagenesis to generate viable human rhinovirus 14 chimeras displaying human immunodeficiency virus type 1 V3 loop sequences. J Virol. 1994;68(1): 575-579. 
254. Brown T, Peerapatanapokin W. The Asian Epidemic Model: a process model for exploring HIV policy and programme alternatives in Asia. Sex Transm Infect. 2004;80 Suppl 1:i19-i24.

255. Phoolcharoen W. HIV/AIDS prevention in Thailand: success and challenges. Science. 1998;280(5371):1873-1874.

256. Weniger BG, Limpakarnjanarat K, Ungchusak K, et al. The epidemiology of HIV infection and AIDS in Thailand. AIDS. 1991;5 Suppl 2: S71-S85.

257. Nitayaphan S, Brown AE. Preventive HIV vaccine development in Thailand. AIDS. 1998;12 Suppl B:S155-S161.
258. Hanenberg RS, Rojanapithayakorn W, Kunasol P, Sokal DC. Impact of Thailand's HIV-control programme as indicated by the decline of sexually transmitted diseases. Lancet. 1994;344(8917):243-245.

259. Nelson KE, Celentano DD, Suprasert S, et al. Risk factors for HIV infection among young adult men in northern Thailand. JAMA. 1993;270(8):955-960.

260. Rerks-Ngarm S, Brown AE, Khamboonruang C, Thongcharoen P, Kunasol P. HIV/AIDS preventive vaccine 'prime-boost' phase III trial: foundations and initial lessons learned from Thailand. AIDS. 2006;20(11):1471-1479.

\section{Publish your work in this journal}

Drug Design, Development and Therapy is an international, peerreviewed open-access journal that spans the spectrum of drug design and development through to clinical applications. Clinical outcomes, patient safety, and programs for the development and effective, safe, and sustained use of medicines are a feature of the journal, which has also been accepted for indexing on PubMed Central. The manuscript management system is completely online and includes a very quick and fair peer-review system, which is all easy to use. Visit http://www.dovepress.com/testimonials.php to read real quotes from published authors.

Submit your manuscript here: http://www.dovepress.com/drug-design-development-and-therapy-journal 